\title{
Intriguing minerals: corundum in the world of rubies and sapphires with special attention to Macedonian rubies
}

\author{
Miha Jeršek ${ }^{1} \cdot$ Gligor Jovanovski' ${ }^{2}$ (1) Blažo Boev ${ }^{3} \cdot$ Petre Makreski $^{4}(\mathbb{C}$
}

Received: 22 December 2020 / Accepted: 7 April 2021

(c) The Author(s), under exclusive licence to Springer Nature Switzerland AG 2021

\begin{abstract}
This lecture text presents features of the fascinating mineral corundum and its gem varieties, ruby and sapphire. The geologic occurrences of its varieties and the best-known world localities are presented in detail. The mineralogy and crystallography of corundum, as well as its occurrence forms, are discussed. The origin of their colour varieties and their usage are described, in addition to their important physical characteristics. Applications in the watch and laser industries and as an abrasive material, among others, are included. The ruby variety from dolomite marble in North Macedonia exhibits the unique optical phenomenon known as diasporescence-the inclusion of diaspore crystals in the corundum matrix. This phenomenon affects the parting of corundum crystals and influences their colour, density and hardness. Therefore, special attention is paid here to morphological and physical characteristics of the Macedonian gem corundum.
\end{abstract}

Keywords Corundum $\cdot$ Ruby $\cdot$ Sapphire $\cdot$ Diasporescence $\cdot$ Sivec $\cdot$ North Macedonia

\section{Introduction}

Among more than 5688 currently valid mineral species claimed by the International Mineralogical Association listed in March 2021 [1], corundum $\left(\mathrm{Al}_{2} \mathrm{O}_{3}\right)$ emerges as one of the most sought-after gemstones, mainly owing to its variety of vivid colours, diversity of cut-shape forms and its hardness. Corundum is classified as the third hardest natural material, after diamond $(\mathrm{C})$ and moissanite $(\mathrm{SiC})$. As a result of its extreme hardness, durability and other favourable physical and optical properties, commercial synthesis began

Gligor Jovanovski

gligor@pmf.ukim.mk

$\triangle$ Petre Makreski

petremak@pmf.ukim.mk

1 Slovenian Museum of Natural History, Prešernova 20, 1000 Ljubljana, Slovenia

2 Research Center for Environment and Materials, Academy of Sciences and Arts of North Macedonia, MASA, Bul. Krste Misirkov 2, 1000 Skopje, North Macedonia

3 Faculty of Natural and Technical Sciences, Goce Delčev University, Štip, North Macedonia

4 Institute of Chemistry, Faculty of Natural Sciences and Mathematics, Ss. Cyril and Methodius University in Skopje, Arhimedova 5, 1000 Skopje, North Macedonia
120 years ago, boosting its wide use and the range of applications. Corundum and its gem varieties, ruby and sapphire, have been the subject of extensive scientific interest in the past, especially during the last two decades [2-35], where the main research interest has centred on mineral deposits, mineral age and origin, their colour varieties related to impurities present, their mineralogical, crystallographic and physical properties and their fluorescence; their use as gemstones, abrasives, in the watch industry, as lasers and in optics; and, finally, their synthetic crystal growth. Once reserved for royalty, the fascinating crystals of the red rubies and blue sapphires are presently accessible and available to a wider range of customers, gemstone researchers, hobby mineral collectors and mineral admirers. These are more than enough reasons to take a closer look at this precious stone, to which textbooks of chemistry usually do not pay much attention.

\section{Geological genesis of corundum and its formation mechanism}

Four main periods of corundum formation are recognised worldwide [29, 36]. The oldest known deposit is located in the Archean metamorphic series (2.97-2.6 billion years ago, or Ga) of southwest Greenland. The second period 
of corundum formation was the Pan-African orogeny (750-450 million years ago, Ma). This includes primary ruby and sapphire deposits in the gemstone belt of East Africa, Madagascar, India and Sri Lanka, which are linked to collisional processes that occurred between eastern and western Gondwana, during Pan-African tectonic-metamorphic events [37]. The third period corresponds to the Cenozoic Himalayan orogeny (45 Ma to the Quaternary). Examples include the marble-hosted ruby deposits in Central and Southeast Asia, which occur in metamorphic blocks that were affected by major tectonic events during the collision of the Indian and Eurasian plates [9]. The fourth period of corundum formation is dominated by the extrusion of alkali basalts in the Cenozoic (65 Ma to Quaternary). Such sapphire and ruby deposits occur from Tasmania through eastern Australia, in Southeast Asia, from eastern China to far-eastern Russia [36], in Nigeria and Cameroon, France, Madagascar [31, 32, 38] and recently in Ethiopia [39].

The mineral corundum has been found in magmatic, metamorphic and sedimentary rocks. Corundum is a hightemperature mineral that forms naturally by metamorphism of alumina-rich rocks under amphibolite and granulite facies conditions, at temperatures between 500 and $800{ }^{\circ} \mathrm{C}$ [10]. Gem-quality corundum can be found in magmatic deposits in plutonic and volcanic rocks. It primarily crystallises in plutonic rocks as an accessory mineral in environments deficient in silica, in syenites or nepheline syenites. Rubies and sapphires can be also sighted in volcanic rocks such as continental alkali basalt. Many deposits are associated with corundum formation dominated by the extrusion of alkali basalts where gem-quality corundum occurs as xenocrysts or megacrysts in xenoliths or enclaves incorporated in magmas during their ascent.

Numerous profound and comprehensive reviews and original scientific papers concerning the geological genesis of corundum and its formation mechanisms have been published in the literature, particularly over the last two decades as knowledge of corundum deposit formation has improved significantly $[9,16,19,31-33,40-43]$. Classification systems of corundum deposits have evolved over time, and are based on different mineralogical and geological features (morphology of corundum, geological context of the deposits, genetic processes of corundum formation, genetic type of the deposits, among others) [31, and the references therein]. According to Giuliani [33], recently, gem corundum deposits from primary and secondary deposits are stratified into three main types. Primary ruby deposits are subdivided into two types based on their geological environment of formation: Type I (magmatic) and Type II (metamorphic). Type I deposits contain two subtypes: (1) subtype IA-rubies, either as xenocrysts or in xenoliths hosted by magmatic rocks, such as alkali basalts; (2) subtype IB-xenocrysts of ruby in kimberlite. Type II deposits contain two subtypes: (1) subtype IIA-metamorphic deposits, sensu stricto in metamorphosed mafic and ultramafic rocks (subtype IIA1) and marble (subtype IIA2); (2) subtype IIB-metamorphic-metasomatic deposits, characterised by high fluid-rock interactions and metasomatism (subtype IIB1), and metasomatites and marble, and shear zone-related or fold-controlled metasomatic-metamorphic deposits, in corundum-bearing $\mathrm{Mg}-\mathrm{Cr}$-biotite schist and in gneiss or marble (subtype IIB2).

Secondary ruby deposits are defined as Type III, i.e. sedimentary-related. These are divided into three subtypes hosted in sedimentary rocks: (1) subtype IIIA-gem placers in alkali basalt environments; (2) subtype IIIB-gem placers in metamorphic environments; (3) subtype IIIC-gem placers with ruby originating from multiple unknown sources.

Depending on the locality where the corundum crystals are grown, the geological context of the deposits, genetic type of the deposits, present mineral associations at the locality, and conditions of pressure and temperature at the corresponding deposit, among other factors, various models and mechanisms of corundum formations have been proposed in the literature, followed by various types of chemical reactions; as an illustration, only a few of them will be mentioned here. According to Mercier [44], the corundum in the Mangari gem mining district in Kenya is formed by the following reactions:

$$
\begin{aligned}
& \text { Sapphirine }\left((\mathrm{Al}, \mathrm{Mg})_{8}(\mathrm{Al}, \mathrm{Si})_{6} \mathrm{O}_{20}\right)+\text { water }\left(\mathrm{H}_{2} \mathrm{O}\right) \\
& \quad \rightarrow \text { corundum }\left(\mathrm{Al}_{2} \mathrm{O}_{3}\right)+\text { chlorite* }+ \text { spinel }\left(\mathrm{MgAl}_{2} \mathrm{O}_{4}\right)
\end{aligned}
$$

$$
\begin{aligned}
& \text { Anorthite }\left(\mathrm{CaAl}_{2} \mathrm{Si}_{2} \mathrm{O}_{8}\right)+\text { water }\left(\mathrm{H}_{2} \mathrm{O}\right) \\
& \quad \rightarrow \text { corundum }\left(\mathrm{Al}_{2} \mathrm{O}_{3}\right)+\text { zoisite }\left(\mathrm{Ca}_{2} \mathrm{Al}_{3}\left(\mathrm{SiO}_{4}\right)_{3}(\mathrm{OH})\right) \\
& \quad+\text { silica }\left(\mathrm{SiO}_{2}\right)
\end{aligned}
$$

*The chlorites are a group of minerals with the general formula $(\mathrm{Mg}, \mathrm{Fe})_{3}(\mathrm{Si}, \mathrm{Al})_{4} \mathrm{O}_{10}(\mathrm{OH})_{2} \cdot(\mathrm{Mg}, \mathrm{Fe})_{3}(\mathrm{OH})_{6}$.

Spiridonov [41] proposed a hypothesis for the ruby formation mechanism in the deposits of Turakuloma, Pamirs, and the Uralian folded areas, where ruby is associated with carbonate minerals, scapolite $\left(\mathrm{Na}_{2} \mathrm{Ca}_{2} \mathrm{Al}_{5} \mathrm{Si}_{7} \mathrm{O}_{24} \mathrm{Cl}\right)$ and fuchsite $\left(\mathrm{KAl}_{2}\left(\mathrm{Si}_{3} \mathrm{Al}\right) \mathrm{O}_{10}(\mathrm{OH}, \mathrm{F})_{2}\right)$. The model is based on experiments and petrological observations which show that, at a high $\mathrm{CO}_{2}$ fugacity, spinel breaks down into corundum according to the following reaction:

$$
\begin{aligned}
& \text { Spinel }\left(\mathrm{MgAl}_{2} \mathrm{O}_{4}\right)+\mathrm{CO}_{2} \\
& \quad \rightarrow \text { corundum }\left(\mathrm{Al}_{2} \mathrm{O}_{3}\right)+\text { magnesite }\left(\mathrm{MgCO}_{3}\right)
\end{aligned}
$$

Kissin [40] observed the formation of ruby in marble in the Urals from the destabilisation of spinel between 620 and $660{ }^{\circ} \mathrm{C}$ and at pressure of approximately $2.5 \mathrm{kbar}$. The formation of corundum by spinel breakdown is the main reaction observed in ruby deposits from Southeast and Central 
Asia [43]. In this ruby belt, the reaction proposed by Spiridonov [41] does not occur, and magnesite has never been identified. The thermodynamic conditions favourable for spinel breakdown are given according to the following reaction:

$$
\begin{aligned}
& \text { Spinel }\left(\mathrm{MgAl}_{2} \mathrm{O}_{4}\right)+\text { calcite }\left(\mathrm{CaCO}_{3}\right)+\mathrm{CO}_{2} \\
& \leftrightarrow \text { corundum }\left(\mathrm{Al}_{2} \mathrm{O}_{3}\right)+\text { dolomite }\left(\mathrm{CaMg}\left(\mathrm{CO}_{3}\right)_{2}\right)
\end{aligned}
$$

\section{Origin of names}

The name corundum comes from its Sanskrit name koruvinda (kurund in Hindi). The name ruby comes from the Latin word ruber and means red stone. Sapphirus (Latin) and sappheiros (Greek)-meaning "blue stone"-refers to lapis lazuli, an ancient rock composed of three minerals: lazurite $\left(\mathrm{Na}_{3} \mathrm{Ca}\left(\mathrm{Si}_{3} \mathrm{Al}_{3}\right) \mathrm{O}_{12} \mathrm{~S}\right)$, calcite $\left(\mathrm{CaCO}_{3}\right)$ and pyrite $\left(\mathrm{FeS}_{2}\right)$. The content of lazurite is essential for the gem's "bright royal" blue colour. Some believe it is derived from the Sanskrit word sanipriya, meaning "dear to Saturn".

\section{Mineralogy and crystallography of corundum}

Corundum contains aluminium (52.9 mass \%) and oxygen $\left(47.1\right.$ mass \%) [46, 47], with the chemical formula $\mathrm{Al}_{2} \mathrm{O}_{3}$. It crystallises in a hexagonal scalenohedral class of the trigonal crystal system, with unit cell parameters $a=476.02 \mathrm{pm}$ and $c=1299.46 \mathrm{pm}$, and an axis ratio $a / c=1: 2.7298$ [47]. The oxygen atoms in the corundum structure are approximately hexagonally close-packed and the aluminium atoms occupy the octahedral sites (Fig. 1, $p=1$ bar) [48]. The corundum structure resembles the hematite-type structure, and crystallises in the space group $R \overline{3} m$ [46].
The mineral is usually massive, roughly crystallised and coarse-to-fine grained [46]. In contrast, some crystals are well developed and weigh up to $100 \mathrm{~kg}$. More than 70 forms of corundum crystals have been observed [49], adopting combinations of pinacoids, rhombohedra, bipyramids and prisms (Table 1) [50].

Generally, the corundum crystals are prismatic (Fig. 2), pyramidal and barrel-shaped and, less commonly, flat, tabular and rhombohedral [50].

Prismatic crystals of corundum are either short-to-long prismatic or prismatic to barrel-like. These crystals are always terminated by pinacoids. Barrel-like crystals can be transitional to pyramidal crystals. Crystals of corundum with only one developed crystal form (bipyramid or rhombohedron) are rare. Often, corundum crystals are elongated in the direction of the $c$ axis. Crystallogenetic trends shows

\begin{tabular}{|c|c|c|c|}
\hline Form & $\begin{array}{l}\text { Sym- } \\
\text { bol }\end{array}$ & Index & $\begin{array}{l}\text { Angle between } \\
c \text { axis and crystal } \\
\text { form }\end{array}$ \\
\hline Pinacoid & c & $(0001)$ & $90^{\circ}$ \\
\hline $\begin{array}{l}\text { Hexagonal prism of } 2 \text { nd } \\
\text { order }\end{array}$ & a & $(11 \overline{2} 0)$ & 0 \\
\hline Positive rhombohedron & $\mathbf{r}$ & $(10 \overline{1} 1)$ & $32.4^{\circ}$ \\
\hline Negative rhombohedron & d & $(01 \overline{1} 2)$ & $51.8^{\circ}$ \\
\hline Negative rhombohedron & $\gamma$ & $(01 \overline{1} 5)$ & $72.5^{\circ}$ \\
\hline \multirow[t]{6}{*}{ Hexagonal bipyramid } & $\mathbf{n}$ & $(22 \overline{4} 3)$ & $28.8^{\circ}$ \\
\hline & $\mathbf{w}$ & $(11 \overline{2} 1)$ & $20.1^{\circ}$ \\
\hline & $\mathbf{v}$ & $(44 \overline{8} 3)$ & $15.4^{\circ}$ \\
\hline & $\mathbf{z}$ & $(22 \overline{4} 1)$ & $10.4^{\circ}$ \\
\hline & $\Upsilon$ & $(44 \overline{8} 1)$ & $5.2^{\circ}$ \\
\hline & $\omega$ & (14.14. $\overline{28} .3)$. & $4.5^{\circ}$ \\
\hline
\end{tabular}

Table 1 Typical morphological forms of corundum crystals [50]
Fig. 1 Stick and ball (a) and polyhedral (b) representations of the corundum crystal structure. Oxygen and aluminium atoms are shown as red and blue, respectively
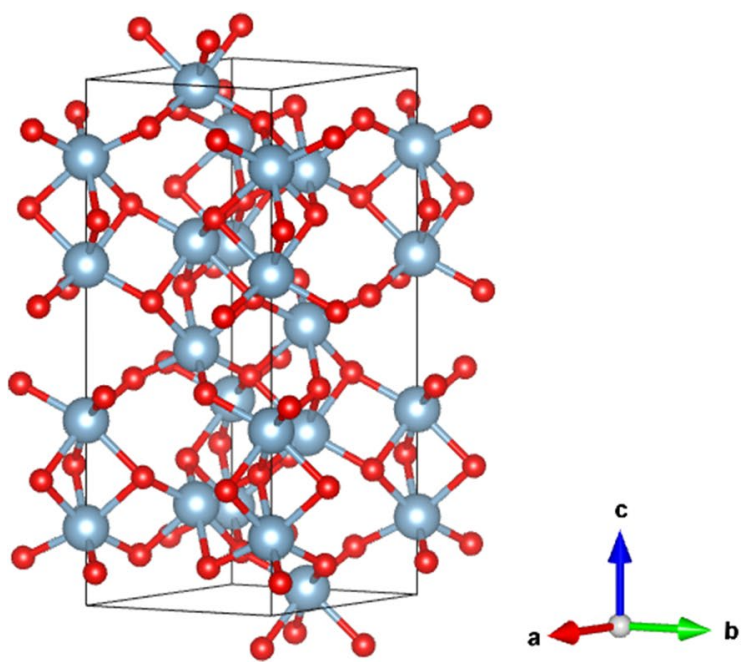

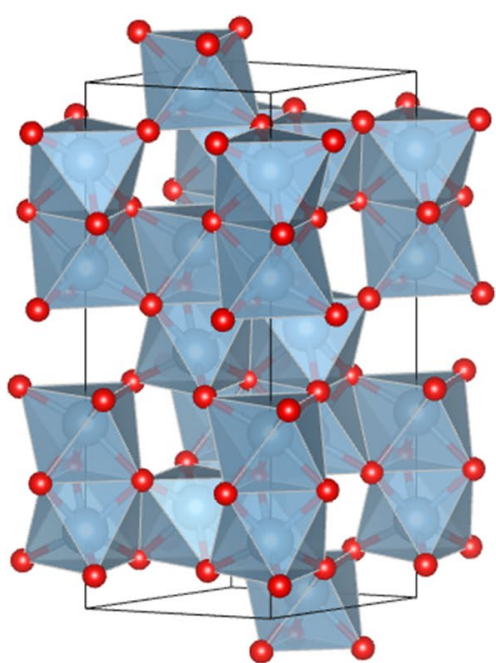




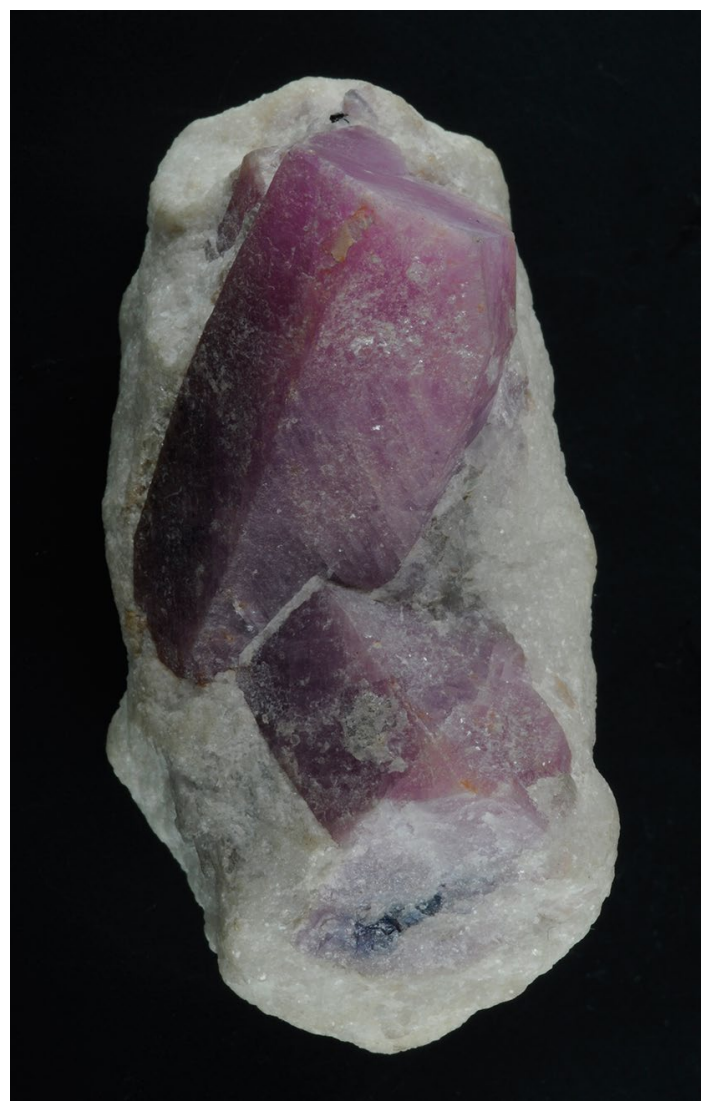

Fig. 2 Prismatic crystals of corundum in dolomitic marble, North Macedonia, $53 \times 27 \mathrm{~mm}$. Collection: Marjetka Kardelj. Photo: Miha Jeršek

that at the lowest temperature $\left(445-448{ }^{\circ} \mathrm{C}\right)$ and pressure (1100 atm), tabular corundum crystals are formed (Fig. 3). At higher pressures, the corundum crystals tendency changes to short prismatic and rhombohedral, whereas pressures of approximately $3500 \mathrm{~atm}$ lead to the occurrence of prismatic crystals [49].

The most typical crystals of corundum are prismatic to barrel-like (Fig. 4, bottom-left). Red varieties of corundum (rubies) are typically less elongated with well-developed pinacoids, whereas the blue varieties of corundum (sapphires) appear most often in bipyramidal forms without pinacoids [50].

Twinning is quite common, but typically is observed under a microscope as a twin lamella. Lamellar twinning produces a lamellar structure and striations occupying the pinacoids and rhombohedra. In fact, these are polysynthetic twins on $\{10 \overline{1} 0\}$ or $\{0001\}$. Other twins of corundum are contact twins and, rarely, penetrated twins. The contact planes are $\{0001\}$ and, rarely, $\{10 \overline{1} 0\}$.

Drawings of idealised corundum crystals are presented in Fig. 5.

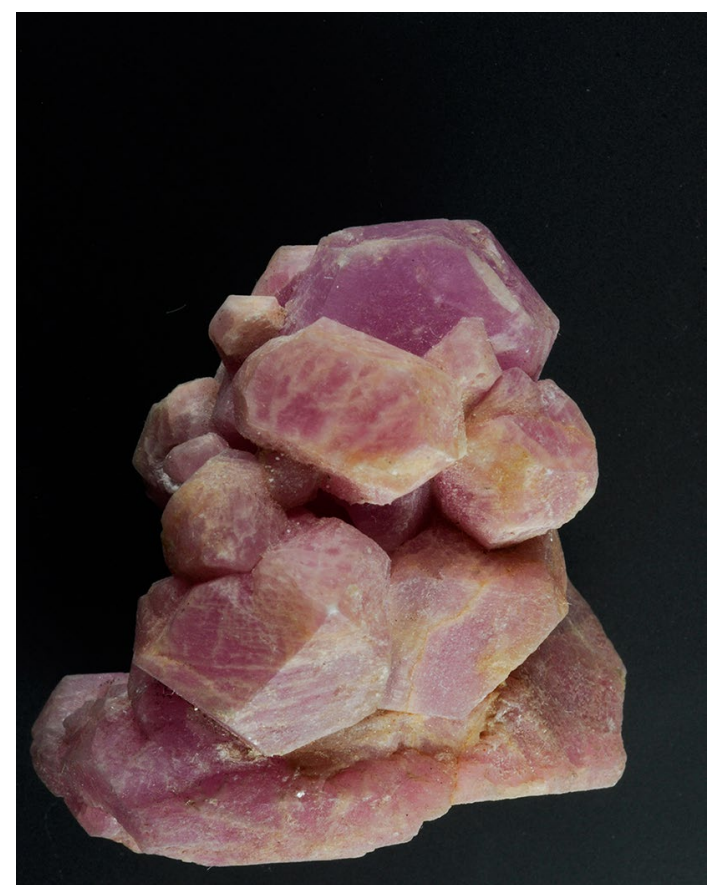

Fig. 3 Cluster of tabular ruby crystals, North Macedonia, $37 \times 43$ mm. Collection: Marjetka Kardelj. Photo: Miha Jeršek

The most characteristic crystal form of corundum from Sivec dolomitic marble in North Macedonia has a developed crystal form of pinacoid $\mathbf{c}$ and hexagonal bipyramid n (Fig. 6/1). The rhombohedra $\mathbf{r}$ crystal form is significant and well developed in tabular crystals with pinacoid $\mathbf{c}$ and hexagonal bipyramid $\mathbf{n}$ (Fig. 6/2,6/3). In addition, a

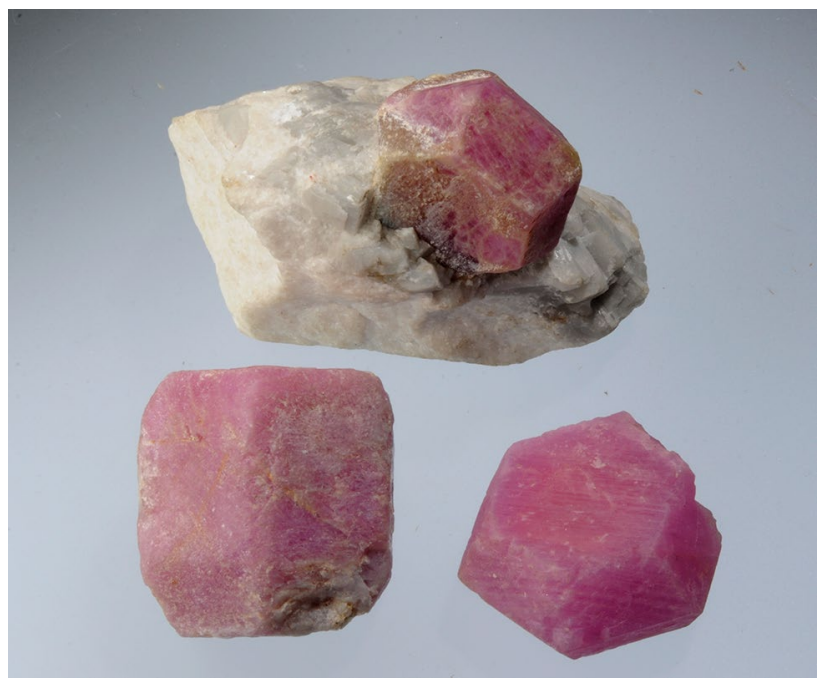

Fig. 4 Typical tabular crystals of rubies (top, $27 \times 27 \mathrm{~mm}$; bottomright, $31 \times 31 \mathrm{~mm}$ ) and a prismatic crystal of ruby (bottom-left, $31 \times 35 \mathrm{~mm}$ ) from Sivec, North Macedonia. Collection: Marjetka Kardelj. Photo: Miha Jeršek 
Fig. 5 Drawings of idealised corundum crystals, adopted from Schmetzer [50]
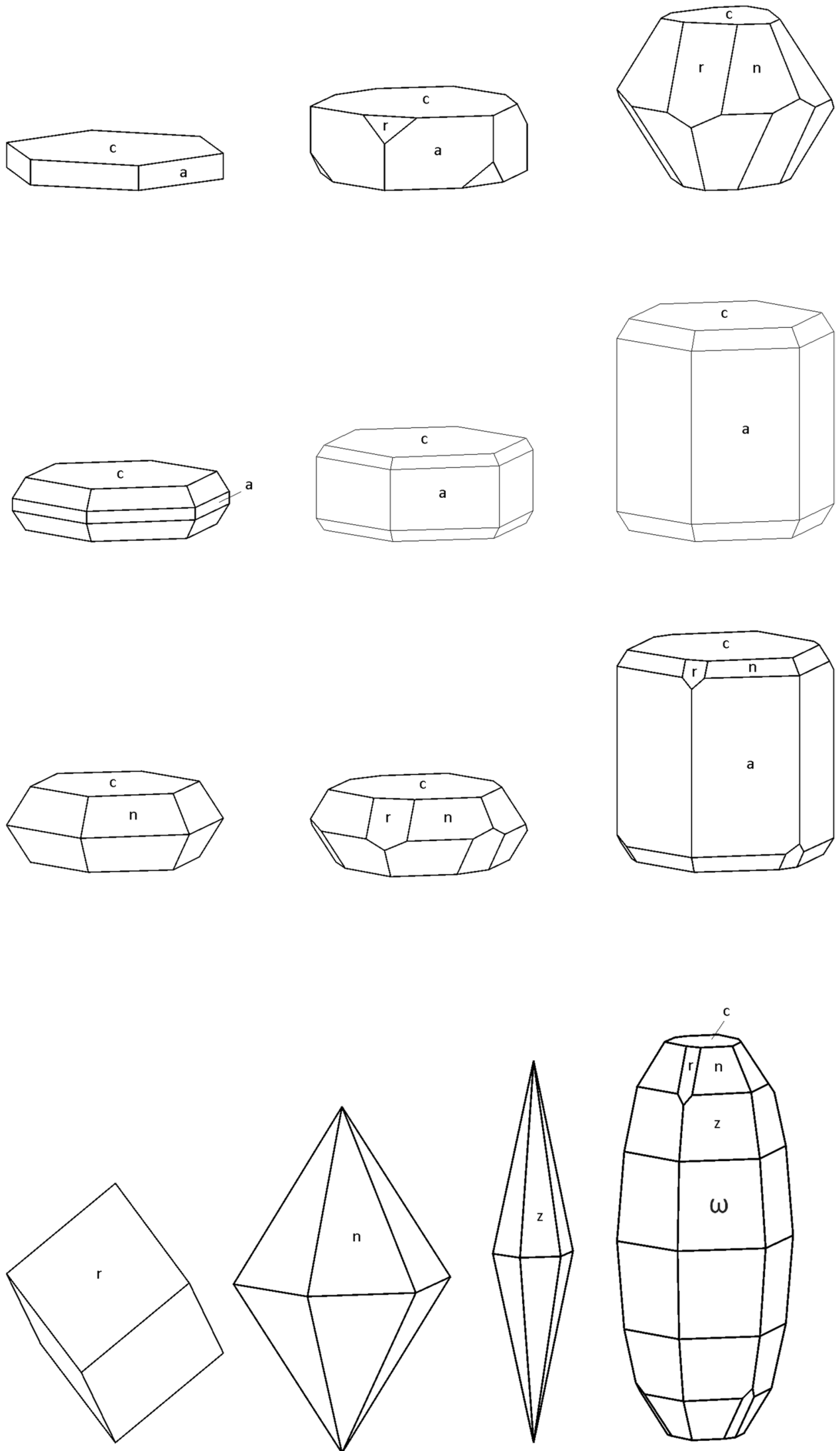
19

Page 6 of 23

ChemTexts

(2021) 7:19

Fig. 6 Drawings of the crystals of corundum from North Macedonia
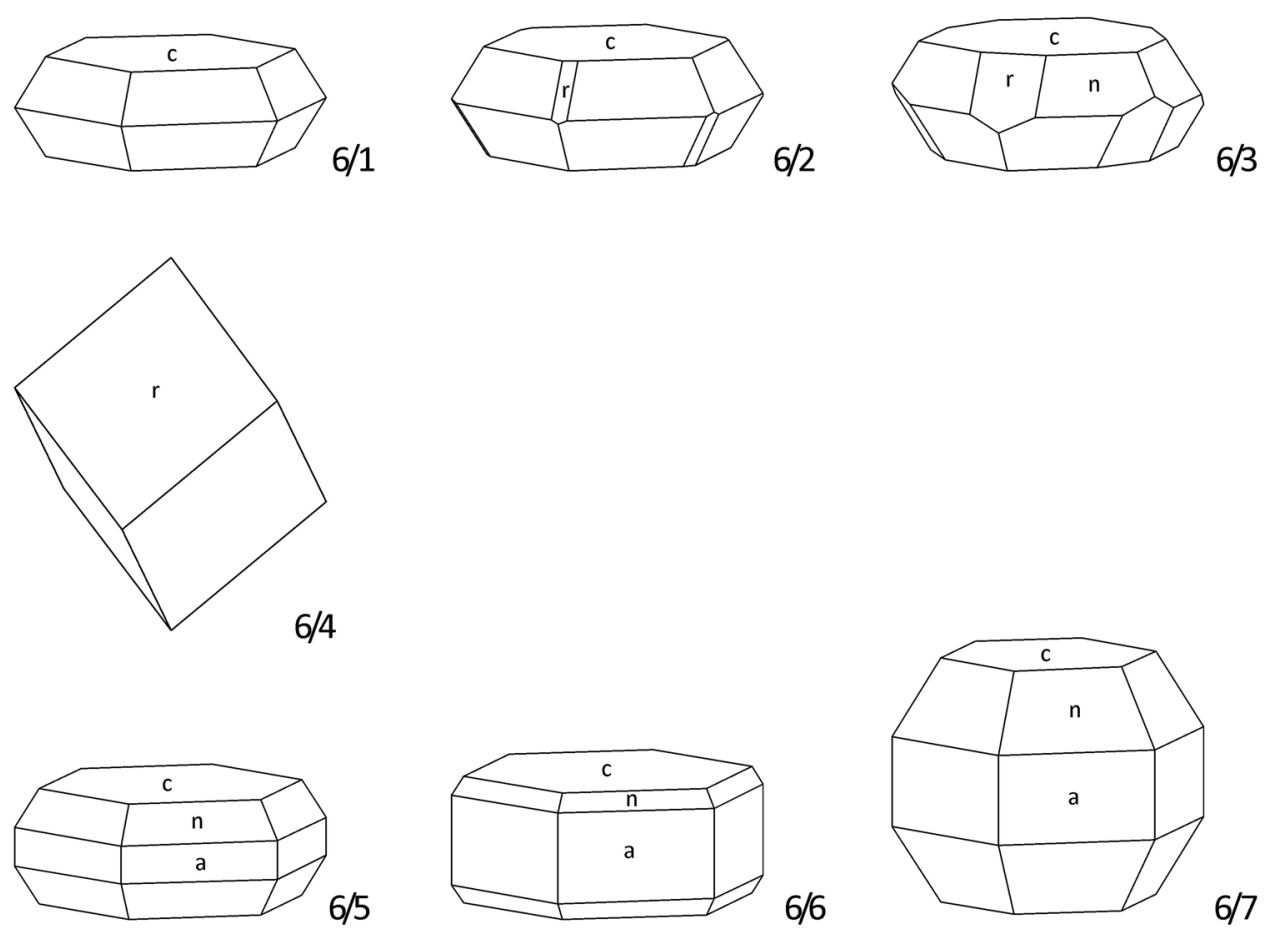

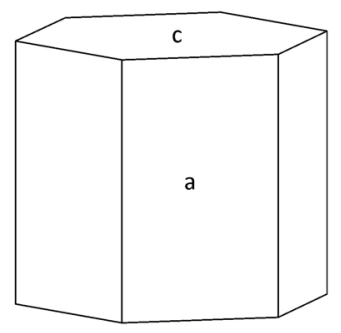

$6 / 9$

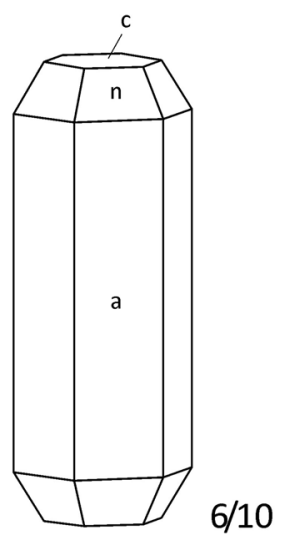

Springer 
corundum crystal has been found with only the crystal form of a positive rhombohedron $\mathbf{r}$ (Fig. 6/4). Such crystals are extremely rare. A crystal form of the second-order prism a is developed in tabular crystals (Fig. 6/5, 6/6) and barrel-like crystals (Fig. 6/7). Occasionally, the dominant crystal form of hexagonal prisms of second-order a exist in combination with pinacoid $\mathbf{c}$ and hexagonal bypiramid $\mathbf{n}$ (Fig. 6/8). On rare occasions, only the crystal form of pinacoid $\mathbf{c}$ and hexagonal prisms of second-order a are observed (Fig. 6/9). Elongated crystals of corundum are also rare. The dominant crystal forms are hexagonal prisms of second-order $\mathbf{a}$ and hexagonal bipyramid $\mathbf{n}$ (Fig. 6/10). The pinacoid $\mathbf{c}$ form is present in almost all crystals of corundum from Sivec dolomitic marble, and only contact twinning on the pinacoid was observed [51]. The oriented overgrowth of corundum by diaspore is highly characteristic, giving the crystal faces a special lustre [52] with an intense silvery glitter.

\section{Physical properties}

\section{Cleavage, fracture and parting}

Cleavage on corundum crystals is not observed, and fracturing is conchoidal to uneven. Parting is significant in three directions on pinacoids $\mathbf{c}\{0001\}$, rhombohedra $\mathbf{r}\{10 \overline{1} 0\}$ and prisms a $\{11 \overline{2} 0\}[46,50]$. Parting in the direction of pinacoids is caused by the oriented mica crystals which grow perpendicular to pinacoids [45]. Parting in the direction of rhombohedra is caused by polysynthetic twinning in the direction of rhombohedra (Fig. 7) [45], by exsolution of boehmite, or by the oriented intergrowth of diaspore and corundum (from North Macedonia) perpendicular to rhombohedron crystal faces [51]. Figure 8 depicts parting in star rubies from India.

\section{Colour}

Colour is one of the primary diagnostic properties in mineralogy, easily visualised by the naked eye, and plays an important role in the process of the mineral identification, but is often not diagnosed. The colour of a mineral can be caused by the major chemical composition [e.g. cinnabar $(\mathrm{HgS})$, azurite $\left(\mathrm{Cu}_{3}\left(\mathrm{CO}_{3}\right)_{2}(\mathrm{OH})_{2}\right)$, malachite $\left.\left(\mathrm{Cu}_{2} \mathrm{CO}_{3}(\mathrm{OH})_{2}\right)\right]$, and thus is diagnostic and identical in such cases (idiochromatic colour). On the other hand, some minerals show variable colours that originate from the presence of trace elements (allochromatic colour), defects in the crystal structure, inclusions or other reasons (e.g. quartz, corundum). Thus, the colour is affected by several factors and its understanding is of particular importance for the valuation of the corundum gemstones. At least two factors are highly important and

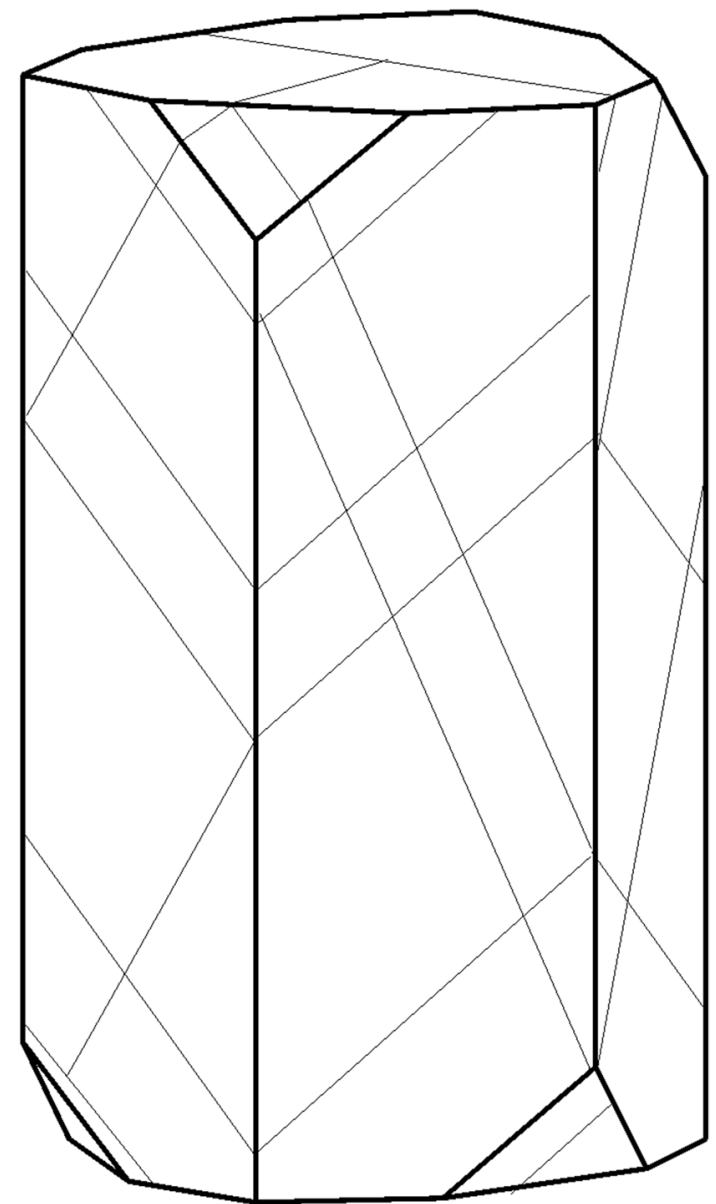

Fig. 7 Parting of corundum, adopted from Schmetzer, 1989 [50]

have significant impact on the price of a corundum stone-the saturation and the hue of the colour.

Before we proceed with this important corundum feature, a brief description of crystal field theory (CFT) is outlined, in order to elucidate some of the reasons for the occurrence of different colour varieties. The theory relies on the assumption that metal-ligand interactions are purely electrostatic in nature, although this assumption is obviously not valid for many complexes (including those containing neutral ligands such as $\mathrm{CO}$ ). Despite its shortcomings, CFT delivers a large degree of accuracy in explaining the electronic structures and colours of metal complexes and minerals. The cornerstone of the theory considers the effect of the arrangement symmetry of ligands on the energy of the $d$ or $f$ orbitals that are part of the central metal atom [53]. The five $d$ orbitals and seven $f$ orbitals of the metal ion are degenerative, and have the same quantum energy level in the absence of any ligand (e.g. $\mathrm{O}^{2-}, \mathrm{OH}^{-}$). However, when ligands approach the central metal ion, $d$ - or $f$-subshell degeneracy is broken because of the static electric field. As a result of the repulsive forces between the electrons that occupy $d$ orbitals (or 


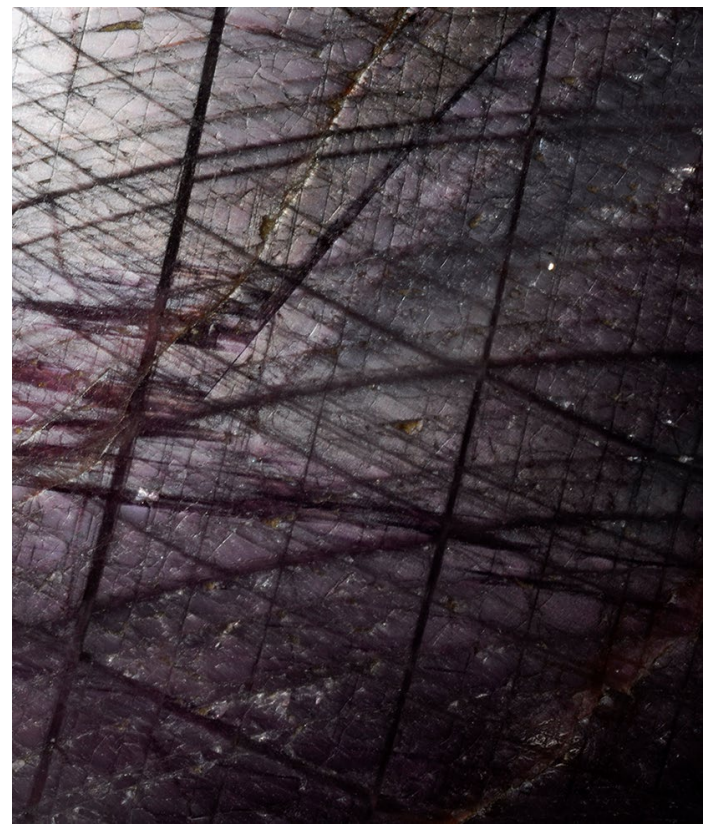

Fig. 8 Parting in star rubies from India, $14 \times 12 \mathrm{~mm}$. Photo: Miha Jeršek

$f$ orbitals) and the electrons of the ligand, the $d$ electrons closer to the ligands attain higher energy than those further away, resulting in the so-called splitting of the $d$ orbitals [54]. In terms of CFT, the splitting is affected by the nature of the metal ion, the oxidation state of the metal (larger splitting for higher oxidation states), the arrangement of the ligands around the metal ion and the nature of the ligands surrounding the metal ion. As explained earlier, each $\mathrm{Al}^{3+}$ cation in corundum is octahedrally coordinated by six oxygens, forming slightly distorted octahedra [48], and the splitting of the $d$ orbitals may occur for the metal cations substituting $\mathrm{Al}$ ions in the corundum structure, which contains unpaired $d$ electrons.

When pure corundum is considered through the prism of CFT, the situation is rather simple. $\mathrm{Al}^{3+}$ contains no orbitals partially filled with electrons, as all electrons in its orbitals are paired. The total pairing of the electrons means that these electrons cannot be excited and, thus, cannot absorb discrete light wavelengths, which ultimately results in no colour (pure $\mathrm{Al}_{2} \mathrm{O}_{3}$ is rarely found in nature and is colourless). However, when other metal atoms (M) replace some of the $\mathrm{Al}^{3+}$, the new atoms must conform to the +3 oxidation state to retain the overall electroneutral charge. Therefore, each metal replacing the $\mathrm{Al}^{3+}$ must also donate three electrons and obtain the $\mathrm{M}^{3+}$ state.

The outer orbitals of the $d$ - and $f$-block atoms exhibit different shapes, and their spatial geometric configuration is directional. If a $d$-block element is considered to replace $\mathrm{Al}$, the $\mathrm{M}^{3+}$ cation contains three unpaired electrons in the

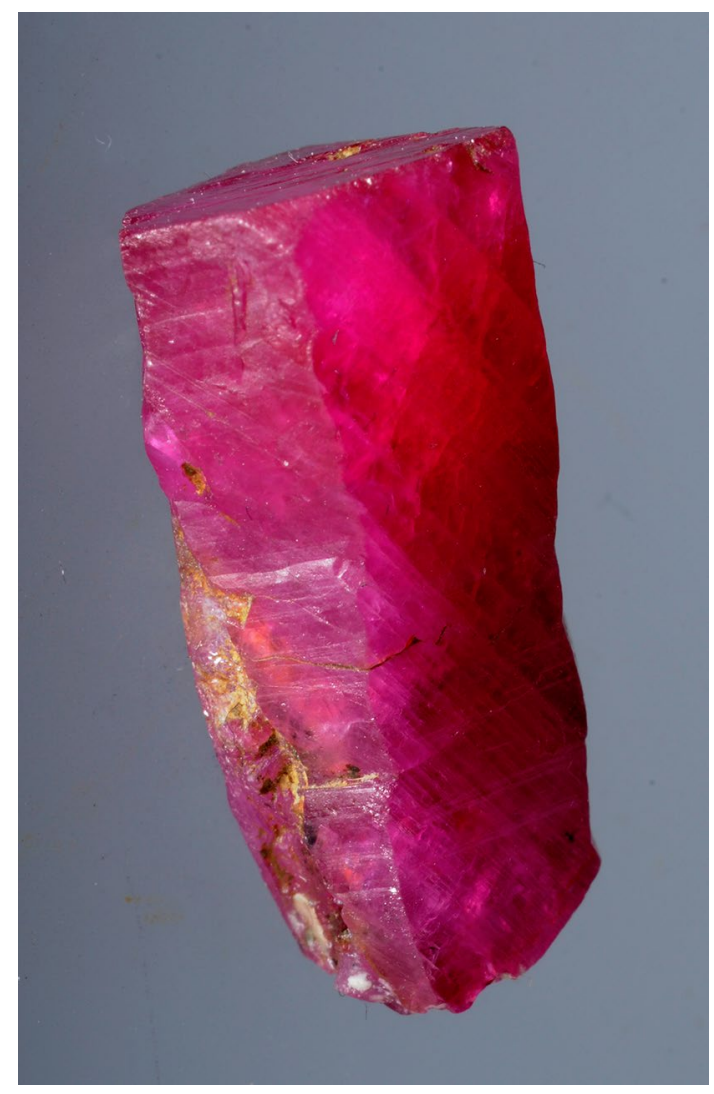

Fig. 9 Ruby from Vietnam, height $19.50 \mathrm{~mm}$. Collection: Marjetka Kardelj. Photo: Miha Jeršek

outer energy level (five $d$ orbitals), meaning that three out of five $d$ orbitals are partially filled [15]. Despite the five $d$ orbitals of the $\mathrm{M}^{3+}$ ion pointing in different directions, if an isolated $\mathrm{M}$ ion was considered, it would not generate any colour and would remain colourless. However, the red colouration in corundum (ruby variety) involves the replacement of several hundred to a few thousand $\mathrm{Al}^{3+}$ ppma (ppma $=$ parts per million atoms) with $\mathrm{Cr}^{3+}$ as impurity [28]. At these structural positions [55], the five $3 d$ orbitals of the $\mathrm{Cr}^{3+}$ ion, surrounded by six oxygen ions (in a distorted octahedral configuration), interact with the orbitals of the six oxygen ligands that, in turn, produce perturbations in the energy levels of the individual orbitals. Thus, the energy of the five $3 d$ orbitals of the $\mathrm{Cr}^{3+}$ ion is no longer the same, and splitting between these energy levels occurs. The splitting is determined by the symmetry, implying that octahedral and tetrahedral ligand field environments will produce different energy shifts. If the energy required for an electron to "hop" to a higher energy level corresponds exactly to the energy of the photon, the light can be absorbed. To satisfy the conservation of energy, the photon energy equals the energy difference between the final and the initial electron state.

In rubies, the energy split difference of the $\mathrm{Cr}^{3+}$ electronic states is equal to the yellow-green and violet wavelengths of 
light. Therefore, when visible light strikes the rubies, these photons (colours) are absorbed by the sample, enabling full transmission of the red wavelengths and minor passage of the blue wavelengths, giving ruby its deep red colour enhanced by some bluish overtones (Fig. 9). The observation of the $3 d$ excited states of the $\mathrm{Cr}^{3+}$ impurities in ruby was the subject of detailed experimental work [24]

The colour occurrence in corundum is addressed in many publications, whereas a very good representation of the causes of this gem's colourations is systematized in reviews [28, 56-59]. Minerals that would be colourless if chemically pure, commonly exhibit a range of colours due to the presence of small quantities of one or more colouring trace elements that are not part of the chemical formula $(\mathrm{Ti}, \mathrm{V}$, $\mathrm{Cr}, \mathrm{Mn}, \mathrm{Fe}, \mathrm{Co}, \mathrm{Ni}$ and $\mathrm{Cu}$ ). As referred at the beginning of this section, these minerals, comprising corundum, beryl, spinel and quartz, are known as allochromatic gemstones. It should be noted that the colour origin may also be attributed to point defects occurring in the crystal lattice during the formation period.

As discussed above, it is well established that the presence of $\mathrm{Cr}^{3+}$ is the cause of the pale pink colour, which turns deep red as its concentration increases [4, 6, 7, 60]. The vibrant blue colour of sapphires (Fig. 10) originating from the presence of $\mathrm{Fe}$ and $\mathrm{Ti}$ chemical impurities was recently explained in detail, providing added value to previous results $[61,62]$. Namely, isolated $\mathrm{Fe}^{3+}$ and $\mathrm{Ti}^{3+}$ incorporation yields yellow and pink crystals, respectively, but their chemical interaction is required to produce the blue colour response $[13,17]$. When in neighbouring lattice sites, a charge transfer between $\mathrm{Fe}$ and $\mathrm{Ti}$ cations can occur: $\mathrm{Fe}^{3+}+\mathrm{Ti}^{3+} \rightarrow \mathrm{Fe}^{2+}+\mathrm{Ti}^{4+}$. The process of electron transfer results in the absorption of energy owing to the overlap of $d$ orbitals on these metals. Thus, an intervalence charge transfer between $\mathrm{Ti}^{3+}$ and $\mathrm{Fe}^{3+}$ was the underlying dominant

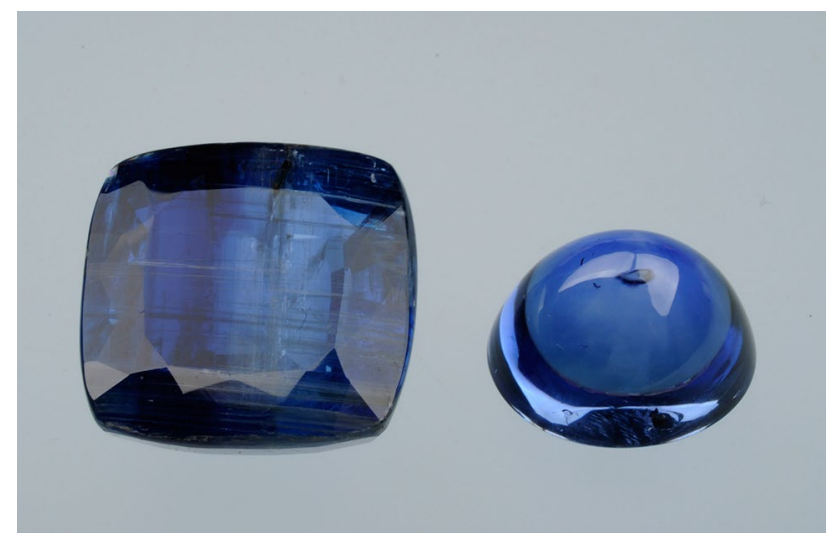

Fig. 10 Sapphire from India (left, 21.85 carat, ct) and from Sri Lanka (right, $11.90 \mathrm{ct}$ ). Collection: Christoph Steidl Porenta, "Zlato runo" jewellery. Photo: Miha Jeršek mechanism postulated for the blue colouration of the sapphires [13] that produced the metastable $\mathrm{Fe}^{2+} / \mathrm{Ti}^{4+}$ configuration [17]. Recently, based on X-ray absorption nearedge structure (XANES) spectra, the energy band model of $\mathrm{Fe}^{3+}-\mathrm{Ti}^{4+}$ mixed acceptor states was formulated to describe the cause of the colour of blue sapphire [21].

Another transition metal which may affect the colour of corundum is the $\mathrm{V}$ chromophore $\left(\mathrm{V}^{3+}\right)$, whose concentration varies significantly depending on the origin of the sample, mainly in rubies or sapphires. The typical $\mathrm{V}^{3+}$ content lies

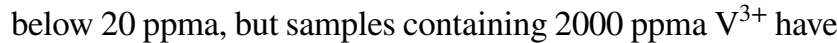
been reported [28, 63, 64]. A minor $\mathrm{V}^{3+}$ content induces slate to purple colours in sapphires. In rubies, the combined high $\mathrm{V}^{3+}$ and high $\mathrm{Cr}^{3+}$ contents results in a purple-red colour, whereas high $\mathrm{V}^{3+}$ with lower $\mathrm{Cr}^{3+}$ contents corresponds to purple, mauve to grey colours [64]. With $\mathrm{V}^{3+}$ substitution, the simpler orbital structure $\left(3 d^{2}\right)$ compared to $\mathrm{Cr}^{3+}$ produces colour (sharp absorption at $475 \mathrm{~nm}$ ), but a stronger crystal field effect of $\mathrm{Cr}^{3+}$ over $\mathrm{V}^{3+}$ enhances red transmission over purple-grey transmission [65].

$\mathrm{Fe}^{3+}$ is the weakest chromophore of the colour centres in corundum, requiring substantial concentration to cause colour effects. Despite this attribute, its determination poses a demanding challenge if one consider its (i) presence as ion replacing the $\mathrm{Al}^{3+}$ ion, (ii) existence as an $\mathrm{Fe}^{3+}$ ion pair or (iii) the incidence of larger $\mathrm{Fe}^{3+}$ clusters. The most characteristic absorption bands in corundum samples occur at 377 and $450 \mathrm{~nm}$, and are attributed to $\mathrm{Fe}^{3+}-\mathrm{Fe}^{3+}$ pairs, whereas the narrow peak at $388 \mathrm{~nm}$ is attributed to single $\mathrm{Fe}^{3+}$ ions [28]. Therefore, the colour manifestation by the presence of the $\mathrm{Fe}^{3+}$ chromophores is weak, and requires high concentrations to produce yellow colour, at a magnitude of a few thousand Fe ppma [28].

Some of the chromophores in the corundum lattice involve so-called trap holes (h•), referring to an oxygen ion with a valence of -1 rather than -2 that is capable of strong light absorption [66]. Trap holes are created in the crystal lattice for charge compensation when trivalent $\mathrm{Al}^{3+}$ is replaced by either of a divalent $\mathrm{Be}^{2+}$ or $\mathrm{Mg}^{2+}$ ion. However, since the $\mathrm{Be}^{2+}$ or $\mathrm{Mg}^{2+}$ ions are not chromophores, the trapped hole associates with $\mathrm{Fe}$ or $\mathrm{Cr}$ cations that produce colour, although the colours caused naturally by $\mathrm{Mg}$ or by diffusion of $\mathrm{Be}$ are highly similar $[59,67,68]$. If the sample contains $\mathrm{Fe}$ but not $\mathrm{Cr}$, the eventual occurrence of the h॰-Fe ${ }^{3+}$ pair yields a strong yellow colour. If the situation is opposite, the formation of h•- $\mathrm{Cr}^{3+}$ may take place, causing a strong orange colour. In the samples where both $\mathrm{Fe}^{3+}$ and $\mathrm{Cr}^{3+}$ are present, the hole will favourably pair with the $\mathrm{Cr}^{3+}$ [28] as the association of the hole with both $\mathrm{Fe}^{3+}$ or $\mathrm{Cr}^{3+}$ is unusual.

Thus, the six major chromophores causing the specified colour of the corundum comprise $\mathrm{Cr}^{3+}$ (pink, red), $\mathrm{Fe}^{3+}-\mathrm{Ti}^{3+}$ (blue), $\mathrm{V}^{3+}$ (grey, green, purple), $\mathrm{Fe}^{3+}$ (yellow), h॰-Fe ${ }^{3+}$ 
(yellow) and h•-Cr ${ }^{3+}$ (orange). The combinations of these primary chromophores produce an extended colouring range of the corundum gems. For instance, green colour arises from the combined presence of $\mathrm{Fe}^{3+}$ (yellow) and $\mathrm{Fe}^{2+}-\mathrm{Ti}^{4+}$ (blue) [67]. Purple or violet occurs as a result of the existence of both $\mathrm{Cr}^{3+}$ (red) with $\mathrm{Fe}^{2+}-\mathrm{Ti}^{4+}$ (blue), whereas the orange is envisaged by cohabitation of the h.- $\mathrm{Cr}^{3+}$ trapped hole (occurring as a result of the presence of $\mathrm{Mg}^{2+}$ ) (yellow) and the $\mathrm{Cr}^{3+}$ (pink) [66, 69-72].

The colours of corundum were also extensively reviewed in the context of heat treatment [73]. Namely, Häger devised a model to understand the causes of colour and colour changes in $\mathrm{Mg}-, \mathrm{Fe}-$ and Ti-bearing natural or synthetic sapphires, at high temperature $\left(1850{ }^{\circ} \mathrm{C}\right)$ in an oxidising environment. The model was described in a Mg-Fe-Ti triangle, representing trace element contents in these stones. The diagram depicted sapphires with relatively low Fe contents, in which the absorption bands of $\mathrm{Fe}^{3+}$ are weak and do not produce a yellow colouration. Häger [73] concluded that all Fe-bearing samples with equal concentrations of $\mathrm{Mg}$ and $\mathrm{Ti}$ atoms were colourless owing to the complete charge compensation by $\mathrm{Mg}-\mathrm{Ti}$ clusters or $\mathrm{Mg}-\mathrm{Ti}$ interactions, resulting in the formation of neither $\mathrm{Mg}$-related hole centres nor Fe-Ti pairs (causing the blue sapphire colour). All corundum samples with $\mathrm{Mg}>\mathrm{Ti}$ compositions revealed $\mathrm{Mg}$ related colour centres, and are yellow, orange or brownishviolet. Most samples where $\mathrm{Ti}>\mathrm{Mg}$ are blue, owing to the presence of the $\mathrm{Fe}^{2+} / \mathrm{Ti}^{4+}$ charge transfer absorption bands in the red-to-green part of the visible range [73, 74].

Interestingly, in 2002, it became apparent that Be could drastically affect and enhance the colour of corundum samples, when inserted by lattice diffusion at high temperatures (over $1800{ }^{\circ} \mathrm{C}$ ). The method facilitates the trading of the corundum gems, as it artificially fabricates yellow, orange and brown colour components, and provides vibrant yellows and oranges in pale-coloured or near-colourless corundum. This new technique invented in Thailand immediately raised conspiracies whether the heating method involved additives. At first, the Thai heaters overruled the claims raised, and the concerns regarding information that no external chemicals were added; later, it was admitted that fluxes and even chrysoberyl were used in the process [75]. Although the actual recipe of the Thai heaters was (and still is) kept under secrecy, several authors unveiled and described their own protocol to mimic this process, in a scientific attempt to decode the underlying mechanism and to provide demystification for the Be diffusion mechanism [67]. The authors created their own flux by adding various chemicals, including finely powdered chrysoberyl, and confirmed the diffusion of Be into rubies and sapphires. The method worked at very high temperatures in an oxygen atmosphere. The major output regarding the colouration implied that, in contrast to the older Ti diffusion process which provided a thin blue layer under the surface, the penetration of Be goes deeper, occasionally manifesting a colouration of the total stone volume. A wide variety of colours were produced or modified, including predominantly yellow, yellowish orange, orangy pink to pinkish orange, orange, and orange-red to red (ruby), depending on how the Be trapped-hole pair interacted with the internal chemistry of the stone [67].

The abundant gas-liquid inclusions in fracture surfaces in some sapphire samples may result in a special optical effect known as chatoyancy, the "cat's eye" effect [25]. This refers to a bright band on the surface of gemstones caused by the reflection of light, whose characteristics depend on the type, size and concentration of the inclusions. Chatoyancy is often observed in gemstones such as chrysoberyl $\left(\mathrm{BeAl}_{2} \mathrm{O}_{4}\right)$, tourmaline $\left[\mathrm{Na}(\mathrm{Fe}, \mathrm{Mg})_{3} \mathrm{Al}_{6}\left(\mathrm{BO}_{3}\right)_{3} \mathrm{Si}_{6} \mathrm{O}_{18}(\mathrm{OH})_{3}\right.$ $(\mathrm{OH})]$ and moonstone $\left[(\mathrm{Na}, \mathrm{K}) \mathrm{AlSi}_{3} \mathrm{O}_{8}\right]$, and recently was revisited in sapphires, although very rarely observed in this case. The chatoyancy effect in other gemstones is induced by parallel needle-like or tubular inclusions, but the underlying occurrence of this effect in sapphire involves a large number of internal parallel fracture surfaces [25].

Substitutional, self-interstitial and interstitial impurities are types of interstitial replacements also observed in corundum, which occur as a result of the structure of the impurity being similar to the host, and these can have major effects on properties of the mineral, including its colour. In addition, ion vacancies are also point defects affecting the colour of the corundum sample. Two divalent $(2+)$ ions can be charge-compensated by an oxygen vacancy, whereas an oxygen interstitial can charge compensate two tetravalent (4+) ions [67]. Likewise, three tetravalent ions can be charge-compensated by an $\mathrm{Al}^{3+}$ vacancy, and an $\mathrm{Al}^{3+}$ interstitial ion can charge compensate three divalent ions. The ionic defects result from the large lattice energy of $\mathrm{Al}_{2} \mathrm{O}_{3}$ [68]. The natural growth of corundum occurs between 250 and $1400{ }^{\circ} \mathrm{C}$, and, at these temperatures, it is assumed that $\mathrm{Ti}$ will more likely be charge-compensated by a divalent ion (e.g. $\mathrm{Mg}^{2+}$ or $\mathrm{Fe}^{2+}$ ), if one is available in the growth medium, then by a vacancy or an interstitial ion. In contrast, for corundum samples grown in the laboratory at temperatures near its melting point (ca. $2045^{\circ} \mathrm{C}$ ) or heat-treated at high temperatures, the more probable charge compensation scenarios are vacancies, interstitial ions, holes or electrons [67].

Taking all of the above into consideration, it becomes apparent that the colour centres and inclusions are the cause of the huge varieties of corundum crystals, from colourless to almost any colour (purple, pink, red, orange, yellow, grey, green, blue, violet, blue and several of their intensities or combinations) (Fig. 11).

Occasionally, crystals of corundum grow under different geochemical conditions. At different stages of crystal growth, a variety of transition metals present at the region 


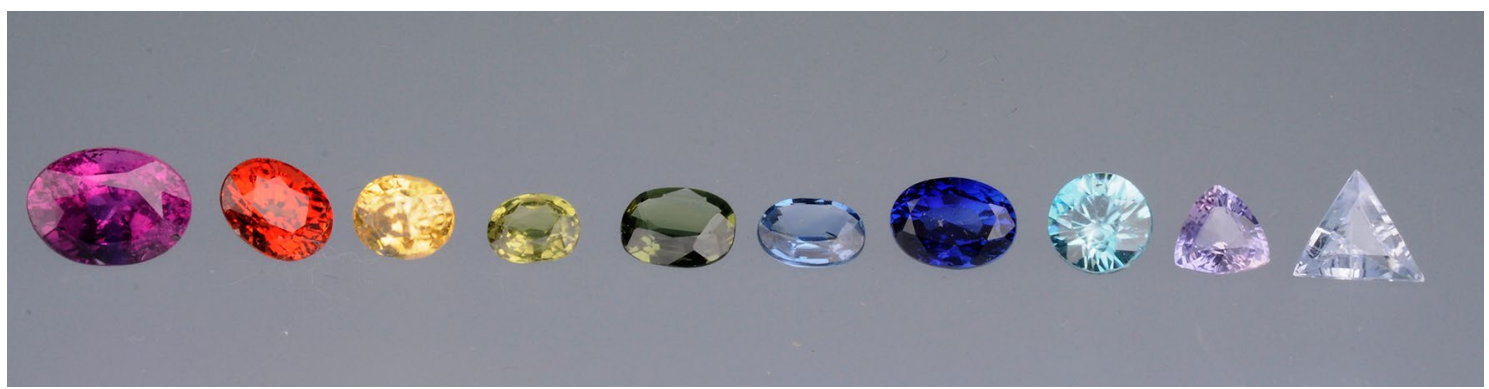

Fig. 11 Corundums in the full range of colours (0.80-1.41 ct). Collection: Christoph Steidl Porenta, "Zlato runo" jewellery. Photo: Miha Jeršek

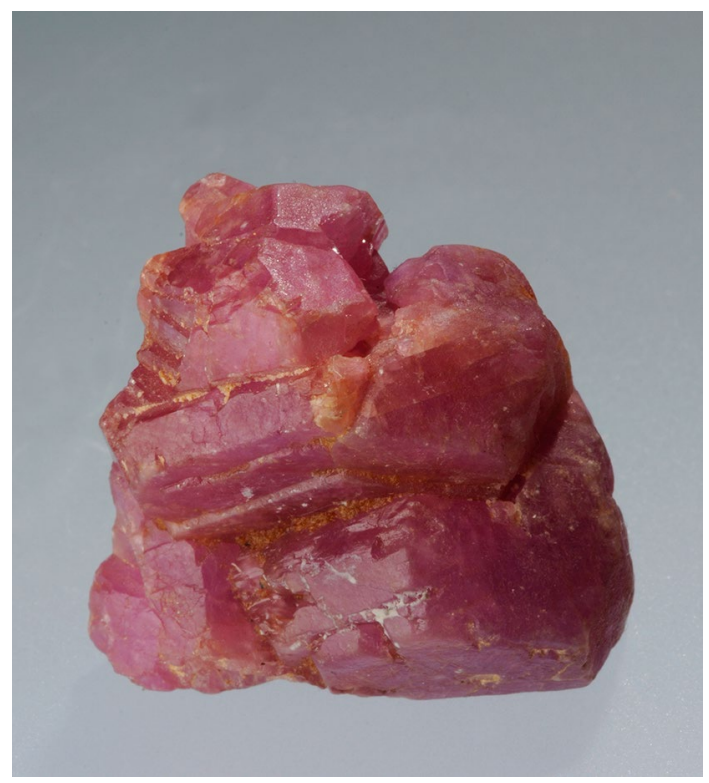

Fig. 12 Rare translucent cluster of ruby crystals from North Macedonia, 27.66×29.48 Collection: Marjetka Kardelj. Photo: Miha Jeršek

of crystallisation are incorporated in the corundum structure. The result is so-called zoning, which unveils a sixfold symmetry of corundum crystals. The typical colour of zoning growth is a combination of colourless or white corundum and blue or red corundum. Such zonings are important signs in the detection of polished gemstones, rubies and sapphires.

The colour of corundum may vary depending on its exposure to transmitted or reflected light, or on whether the crystal specimen is observed with the naked eye or in thin sections under a microscope. The natural transparency of corundum occurs only when its thin sections are spotted. However, these gem-quality samples rarely occur compared to the whole "stock" in the Earth's crust. In general, corundum crystals are translucent or opaque (Fig. 12).

As a result of its trigonal structure, corundum is an optically anisotropic crystal, meaning that its optical properties vary with the direction of light, causing pleochroism. Linear dichroism (often termed pleochroism in mineralogy) is the change in the intensity or hue of a light-absorbing material depending on the direction of the electric field [76]. This property is manifested by having more than one colour when viewed from different angles, and occurs in gem-quality specimens (rarely seen on rough crystals). Thus, rubies under transmitted light depict a red to light red colour, whereas sapphires are dark blue to light blue, or even colourless. The easiest way to determine pleochroism is by using a calcite dichroscope (a small pocket device with a crystal of calcite inside) that enables the observation of transparent corundum in transmitted light as a result of the high birefringence of calcite. By turning on the dichroscope, we examine the facet variety and observe two colours. This is a simple test with which to distinguish ruby from red spinel, as spinel is an isomorphic mineral without pleochroism, and red ruby, as a coloured anisotropic mineral, shows strong pleochroism.

The streak of the coloured corundum varieties is always white, as is typical for minerals whose colour arises from the presence of transition metal elements or colour centres.

The light reflected from the corundum surface affects the lustre of the mineral. Corundum has vitreous, vitreous to adamantine, true adamantine (in high-quality gem material) and pearly lustres on some crystal faces.

The common corundums from North Macedonia are pink to light pink or pink-violet, whereas exquisite samples show an intense reddish, orange or blue colour. The colour depends on the presence of transition metals: $\mathrm{Cr}^{3+}, \mathrm{V}^{3+}$ or $\mathrm{Fe}^{2+} / \mathrm{Ti}^{4+}$. Red to moderately red-violet rubies from North Macedonia contain up to 0.027 mass \% of $\mathrm{Cr}^{3+}$. $\mathrm{V}^{3+}$ has an influence on violetcoloured specimens (up to 0.006 mass \%) and the very rare blue-coloured corundum shows the highest presence of $\mathrm{Ti}^{4+}\left(0.0105\right.$ mass \%). The content of $\mathrm{Fe}^{2+}$ reaches up to 0.025 mass \% [51]. 


\section{Hardness}

The Mohs hardness scale was developed in 1822 by the famous German geologist and mineralogist Carl Friedrich Christian Mohs (1773-1839). This scale quantifies the scratch resistance of minerals by comparing the ability of a harder mineral to scratch a softer mineral, and rating the relative hardness of the various minerals from 1 (softest) to 10 (hardest) (Table 2). On this scale, it is evident that corundum is a very hard mineral, placed on the Mohs scale at level 9 [77]. In contrast, the relative hardness of minerals on the Mohs scale is far away from the absolute hardness scale (Table 2), where numbers are proportionate and measure or compare the actual hardness. For instance, corundum is four times harder than quartz and twice as hard as topaz, but approximately quarter as hard as diamond (Table 2). The absolute value for mineral hardness is determined by means of a scratch with a standardized diamond pyramid, using an instrument called a sclerometer.

Since hardness depends upon the crystallographic direction (ultimately on the strength of the bonds between atoms in a crystal), there may be variations in hardness, depending upon the direction in which one measures this property. The hardness of corundum is not uniform and varies in different directions. Pinacoidal forms exhibit greater hardness than prismatic forms [45], as is well known among cutters of rubies and sapphires. Inclusions of minerals may have an impact on the hardness of corundum as well. Namely, the oriented intergrowth of diaspore in corundum from North Macedonia lowers the hardness by $10 \%$ on average [51]. When testing hardness, it is important to check the surface of crystal faces. Sometimes micas overgrow on pinacoids, boehmite and diaspore on the rhombohedral faces. The hardness test is not frequently used in geological practice, and almost never for gemmological classification. However, the hardness of corundum is a highly important physical feature,

Table 2 Mohs scale of hardness and the absolute hardness

\begin{tabular}{lcc}
\hline Mineral name & Mohs hardness & $\begin{array}{c}\text { Absolute } \\
\text { hardness }\end{array}$ \\
\hline Talc & 1 & 1 \\
Gypsum & 2 & 2 \\
Calcite & 3 & 14 \\
Fluorite & 4 & 21 \\
Apatite & 5 & 48 \\
Orthoclase & 6 & 72 \\
Quartz & 7 & 100 \\
Topaz & 8 & 200 \\
Corundum & 9 & 400 \\
Diamond & 10 & 1500 \\
\hline
\end{tabular}

particularly when exploited for use as abrasives (see later in the text).

\section{Density}

The density of corundum varies between 3.97 and $4.05 \mathrm{~g} \mathrm{~cm}^{-3}$ [45], depending on the impurities and inclusions present in the crystals. For a non-metallic transparent mineral composed of low atomic mass elements ( $\mathrm{Al}$ and $\mathrm{O}$ ), it features a high relative density, positioning corundum in the group of the densest gemstones. The density of rubies and sapphires distinguishes them from other gemstones that feature a common general appearance. Previously, heavy liquids were used to determine the density of gemstones, noting their rapid sink in methylene iodide $\left(3.6 \mathrm{~g} \mathrm{~cm}^{-3}\right)$ [78]. The presence of transition colouring metals in the corundum structure usually does not have substantial impact on its density [79] because of their very low content, typically not exceeding 0.1 mass \%. However, Fe-rich sapphires from Australia and Thailand show higher specific gravities (around $4.0 \mathrm{~g} \mathrm{~cm}^{-3}$ ). As a result of the presence of diaspore inclusions, the density of corundum from Sivec dolomitic marble is considerably lower, ranging between 3.55 and $3.93 \mathrm{~g} \mathrm{~cm}^{-3}$ [51], compared to naturally occurring corundum and synthetic colourless sapphire, which have specific gravities of 3.989 and $3.997 \mathrm{~g} \mathrm{~cm}^{-3}$, respectively.

\section{Refractive index, birefringence and dispersion}

Optical density is the tendency of the atoms in a certain material to restore the absorbed electromagnetic energy. The light travels slower in higher optically dense materials and vice versa. The ratio between the speed of light in a medium (e.g. corundum) to its speed in a vacuum is known as the refractive index. Corundum is an anisotropic, uniaxial mineral with a refractive index $n_{\mathrm{e}}=1.762$ and $n_{\mathrm{o}}=1.770$ $(+0.009,-0.05)$ and birefringence (an optical property of a material having a refractive index that depends on the polarisation and propagation direction of light) of $0.008-0.10$, and the dispersion of light is 0.18 [13]. The refractive index of Macedonian rubies is $n_{\mathrm{o}}=1.760$ and $n_{\mathrm{e}}=1.768$, with birefringence of 0.008 .

\section{Fluorescence}

Fluorescence is the emission of light by a substance that has absorbed light or other electromagnetic radiation (Fig. 13). In most cases, the emitted light has a longer wavelength, and therefore lower energy, than the absorbed radiation. The most striking example of fluorescence occurs when the absorbed radiation is in the ultraviolet region of the spectrum, and thus invisible to the human eye, while the emitted light is in the visible region, which gives the fluorescent 
Fig. 13 Schematic presentation of the quantum energy levels and the corresponding absorption and emission (fluorescence and phosphorescence) processes (adapted from [80])

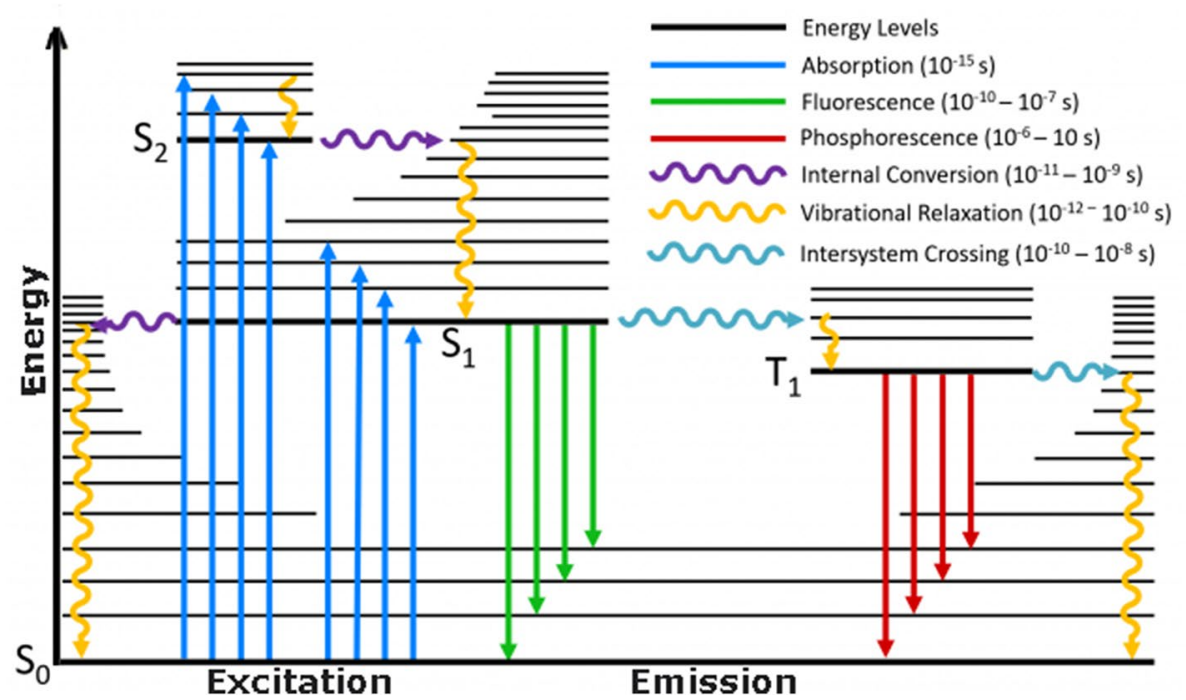

Table 3 Fluorescence of some sapphires

\begin{tabular}{llll}
\hline Sapphire colour & Locality & UV-LW & UV-SW \\
\hline Light blue & Sri Lanka & $\begin{array}{c}\text { Moderate to } \\
\text { strong orange } \\
\text { to red }\end{array}$ & $\begin{array}{l}\text { Weaker orange } \\
\text { to red }\end{array}$ \\
Blue & $\begin{array}{c}\text { Kashmir, } \\
\text { India, Mada- } \\
\text { gascar }\end{array}$ & $\begin{array}{l}\text { Usually inert } \\
\text { Light blue }\end{array}$ & Usually inert \\
Colour change & Africa & Strong red & Weak light red \\
Yellow & Sri Lanka & Strong orange & Orange-yellow \\
Pink & Sri Lanka & Violet & Violet \\
\hline
\end{tabular}

substance a distinct colour that can be seen only when exposed to UV light. Fluorescent materials cease to glow nearly immediately when the radiation source is removed, unlike phosphorescent materials, which continue to emit light for some time after. Fluorescence has many practical applications, including those in mineralogy, geology and gemmology.

Minerals that exhibit fluorescence are known as fluorescent minerals. Fluorescence in minerals is caused by a wide range of particles, known as activators, present in their structure.

Fluorescence of some colour varieties of corundum is significant; in particular, rubies from Myanmar coloured by $\mathrm{Cr}$ display intense red fluorescence under long-wave UV light and weak fluorescence under short-wave UV light. Rubies from Sri Lanka manifest strong orangered (long-wave, LW) and moderate orange-red (shortwave, SW) fluorescence. Rubies from Thailand express weak red fluorescence (UV-LW) and are inert (UV-SW).
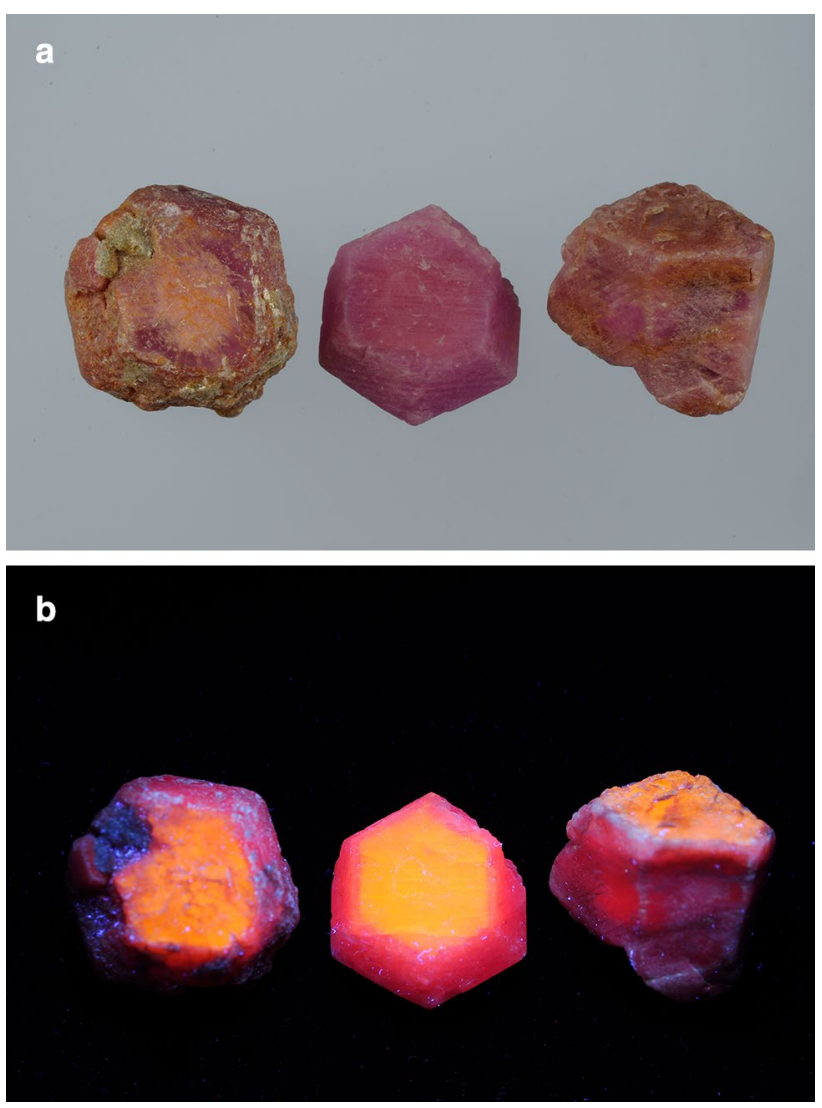

Fig. 14 Corundum crystals from North Macedonia (a) showing orange and red fluorescence in the long-wave ultraviolet light (b) $(34.42 \times 33.86 \mathrm{~mm} ; 31 \times 31 \mathrm{~mm} ; 35 \times 30 \mathrm{~mm})$. Collection: Marjetka Kardelj. Photo: Miha Jeršek

Sapphires are not always blue but also show other colours, and their fluorescence depends on activators (see Table 3). 

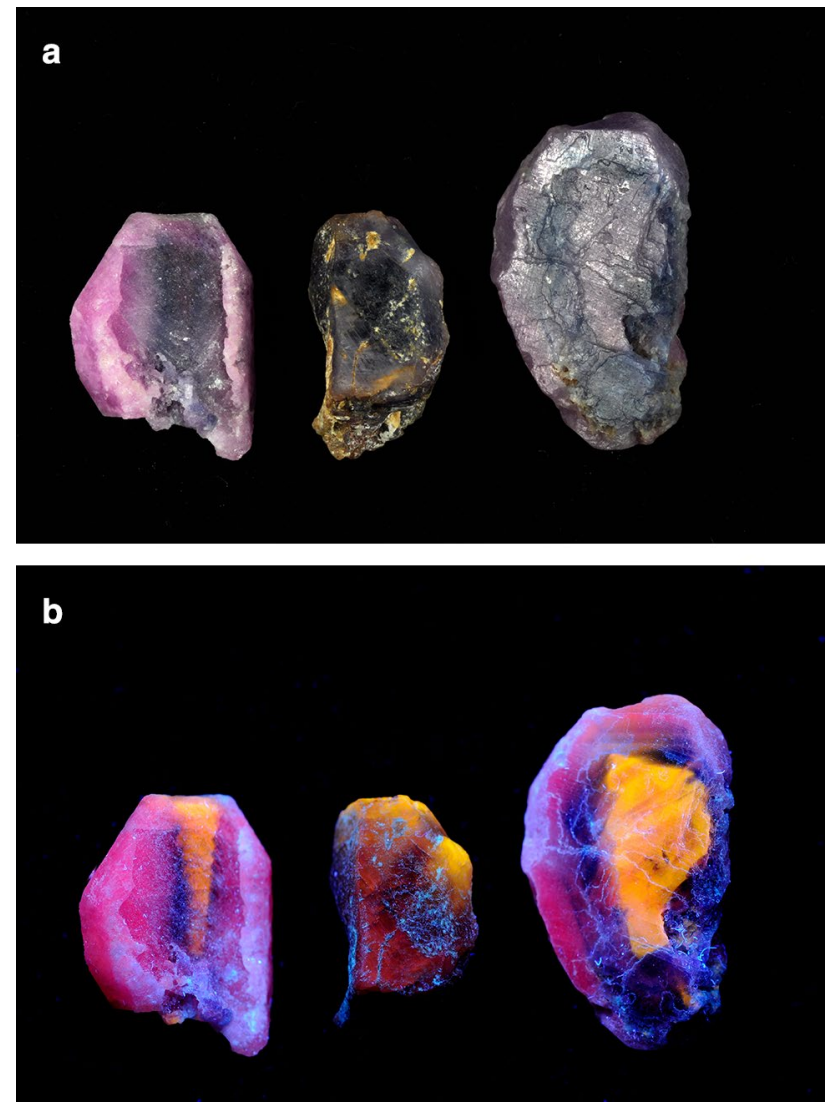

Fig. 15 Cross-section of bicoloured pink-red and blue corundum crystals from North Macedonia (a). The centre and top sections of the crystals show light orange to yellow fluorescence; the blue sections are inert; and the external sections of crystals manifest intense reddish fluorescence (b) $(25 \times 32 \mathrm{~mm}, 17 \times 31 \mathrm{~mm}, 28 \times 44 \mathrm{~mm})$. Collection: Marjetka Kardelj. Photo: Miha Jeršek

The rubies from Sivec locality found in dolomitic marble demonstrate red and orange fluorescence (Fig. 14), while yellow to orange fluorescence is rare and present in blue varieties of corundum (Fig. 15). Many crystals and polished samples show two-colour fluorescence, and, sometimes, the distribution of this two-colour fluorescence may prove the sixfold symmetry of the different coloured zones [51].

\section{Known localities of gem-quality corundum in the world}

Corundum is an accessory mineral in igneous rocks that are not saturated with silica (syenites, nepheline syenite pegmatites) and in high-grade metamorphic rocks, such as marbles and mica-schists [81]. In various types of lava magmatic xenoliths, corundum floats to the surface $[82,83]$. The rocks containing corundums are of different ages and, within each rock, different mineral paragenesis predominates in various deposits. Corundum is relatively resistant to weathering and, therefore, is often found in river sands [84]. Natural corundum of gem quality is scattered over all continents, with more than 2800 deposits in the minerals database [85], providing the geological genesis for the most important localities [5, 21, 22, 33, 45, 81-83, 86, 91-94] (Table 4). Worldwide corundum (ruby) deposits, and the distribution of their major and minor commercial, industrial, scientific and historical world sources, are discussed in detail in the profound review published recently by Giuliani et al. [33].

Three samples of rubies from Vietnam, Cambodia and India are shown in Fig. 16.

Historically, most important deposit of rubies were located in Myanmar; recently, the deposits in Vietnam are more popular. Madagascar became the main source of blue (Fig. 17) and fancy-coloured sapphire over the last three decades [11]. Fine blue sapphires were found in 1994 south of Andranondambo. In 1996, new green and yellow sapphires were discovered at Ankarana, whereas 3 years later sapphires were found at Illakaka and in the deposit of rubies at Vatomandry [23].

In North Macedonia, corundum is embedded in dolomitic marble in the Sivec, Beloto and Belovodica localities [5, 86], in the vicinity of Prilep (Fig. 18), which is about $70 \mathrm{~km}$ south of the capital Skopje. The marble series of thickness $1500 \mathrm{~m}$ represents the uppermost part of highly metamorphic rocks of Precambrian age, which belong to the central part of Pelagonian Massif. The dolomitic marbles are fine-grained and white to grey in colour. The dolomite grains are of an isometric shape, with well-defined polysynthetic lamellae [87]. These marbles are characterised by the following minerals: dolomite, calcite, corundum, diaspore, $\beta$-zoisite, rutile, fluorite, achroite, pyrite, muscovite, illite, margarite and chlorite [88,89]. Besides corundum of gem quality, the largest jewel-quality diaspore in the world was excavated from a quarry in Sivec [52] and described in detail elsewhere [90].

In north Tanzania, Longido District, rubies are found together with zoisite in emerald-green ornamental rock called anyolite (Fig. 19). Tanzania also is a source of rubies in high-grade metamorphic rock in marbles of the Morogoro Region [31].

\section{Corundum as a gemstone}

Corundum as a gemstone does not occur only as either red ruby or coloured sapphire. There are some optical phenomena in gem-quality corundum also manifested by colour alternating-sapphires, star rubies and sapphires, trapiche rubies and sapphires-but also a special, interesting optical phenomenon known as diasporescence. 
Table 4 Selected important deposits of rubies $(\mathbf{O})$ and sapphires $(\mathbf{O})$ across the world [81]

\begin{tabular}{|c|c|c|c|c|c|c|c|c|c|c|}
\hline & $\frac{\frac{\mathscr{O}}{0}}{\sum_{\bar{z}}^{\tilde{z}}}$ & 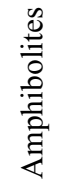 & $\begin{array}{l}0 \\
0 \\
0 \\
0 \\
0 \\
0\end{array}$ & 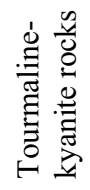 & 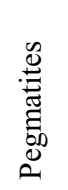 & 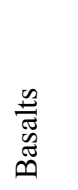 & $\begin{array}{l}\stackrel{0}{0} \\
\stackrel{0}{0} \\
\stackrel{\Xi}{4}\end{array}$ & 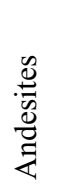 & $\begin{array}{l}\stackrel{0}{\Xi} \\
\stackrel{0}{0} \\
\stackrel{0}{x}\end{array}$ & 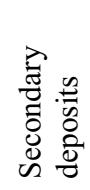 \\
\hline Myanmar & O O ${ }^{[91]}$ & & & & & & & & & $\mathbf{O}^{[21]}$ \\
\hline Thailand & $\mathbf{O}$ & & & & & OO & & & & \\
\hline Vietnam & $\mathbf{O}^{[33]}$ & & & & & & & & & \\
\hline Afghanistan & $\mathbf{O}^{[45,92]}$ & & & & & & & & & \\
\hline Sri Lanka & OO & & & & & & & & & OO \\
\hline India & & & $\mathrm{OO}$ & & $\mathrm{O}$ & & & & & $\mathrm{OO}$ \\
\hline Pakistan & $\mathbf{O}^{[92]}$ & & & & $\mathrm{O}$ & & & & & \\
\hline Kenya & $\mathbf{O}$ & & & $\mathbf{O}$ & & $\mathbf{O}^{[93]}$ & & & $\mathbf{O}^{[93]}$ & \\
\hline Tanzania & $\mathbf{O}$ & O O & O & & O O & & $\mathbf{O}^{[22]}$ & & & \\
\hline Nepal & $\mathbf{O}$ & & & & & & & & & \\
\hline $\begin{array}{l}\text { North } \\
\text { Macedonia }\end{array}$ & $\mathbf{O}^{[5,86]}$ & & & & & & & & & \\
\hline Australia & & & & & & $\mathbf{O}$ & & & $\mathrm{O}^{[82]}$ & \\
\hline Cambodia & & & & & & $\mathrm{O}$ & & & & \\
\hline China & & & & & & O & & & & \\
\hline Nigeria & & & & & & $\mathrm{O}$ & & & & \\
\hline Brazil & & & & & $\mathrm{O}$ & & & & & \\
\hline Scotland & & & & & & & & & $\mathrm{O}^{[83]}$ & \\
\hline Tajikistan & $\mathbf{O}^{[94]}$ & & & & & & & & & \\
\hline Montana & & & & & & & & $\mathrm{O}$ & & \\
\hline
\end{tabular}

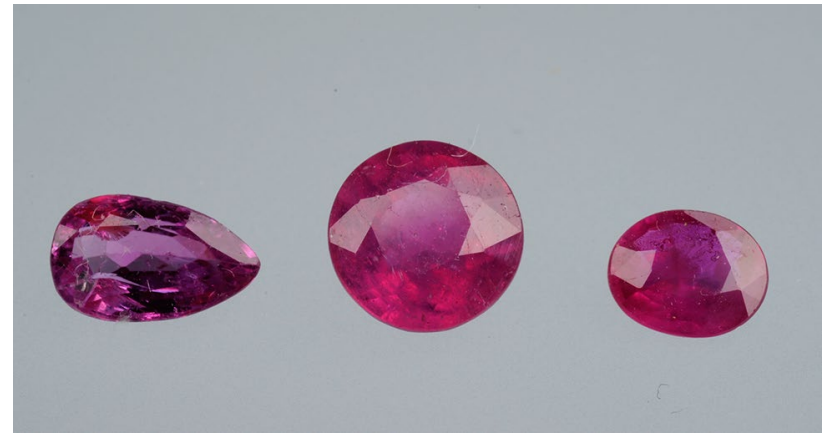

Fig. 16 Rubies from Vietnam $(0.65 \mathrm{ct})$, Cambodia $(1.25 \mathrm{ct})$ and India $(0.40 \mathrm{ct})$ (from left to right). Collection: Christoph Steidl Porenta, "Zlato runo" jewellery. Photo: Miha Jeršek

Ruby is one of the most desirable and precious gems with typical red colour, but gem varieties with pink to violet colour are also attractive (Fig. 20).

Ruby is coloured owing to the presence of $\mathrm{Cr}$. Such stones have moderate red fluorescence in UV-SW and intense red fluorescence in UV-LW. Among these, the most valuable and expensive rubies originate from Myanmar (formerly Burma) with an apparent deep red colour, sometimes called pigeon's red. The Myanmar rubies have a red to slightly purplish-red colour, with vivid saturation. Rubies from this country are highly limited. Over the last 20 years, rubies from Vietnam became highly popular owing to their special tint of red colour, named Vietnam red. Rubies from Thailand contain more $\mathrm{Fe}$ in their structure, explaining their darker-red to redbrown, brownish-red or purplish-red colour. As a result of the low content of $\mathrm{Cr}$, the Thai rubies show neither UV-SW nor weak red fluorescence (UV-LW). Rubies from Sri Lanka (formerly Ceylon) have red colours lighter in tone and are more brilliant than rubies from other mentioned localities. These rubies have a strong orange-red (UV-LW) to moderate orange-red (UV-SW) fluorescence. The presence of transition metals causes a variation in basic colour. $\mathrm{V}$, aside from $\mathrm{Cr}$ and $\mathrm{Fe}$, also plays a vital role in ruby colouration. Faceted stones of finest-quality rubies range from a size of melee (0.001-0.2 ct) to $5 \mathrm{ct}$. Large crystals of rubies have been found in anyolite in Tanzania, and are associated with green zoisite and black hornblende. They have significant, pronounced colour zoning and extend to $10 \mathrm{~cm}$ in diameter. One 

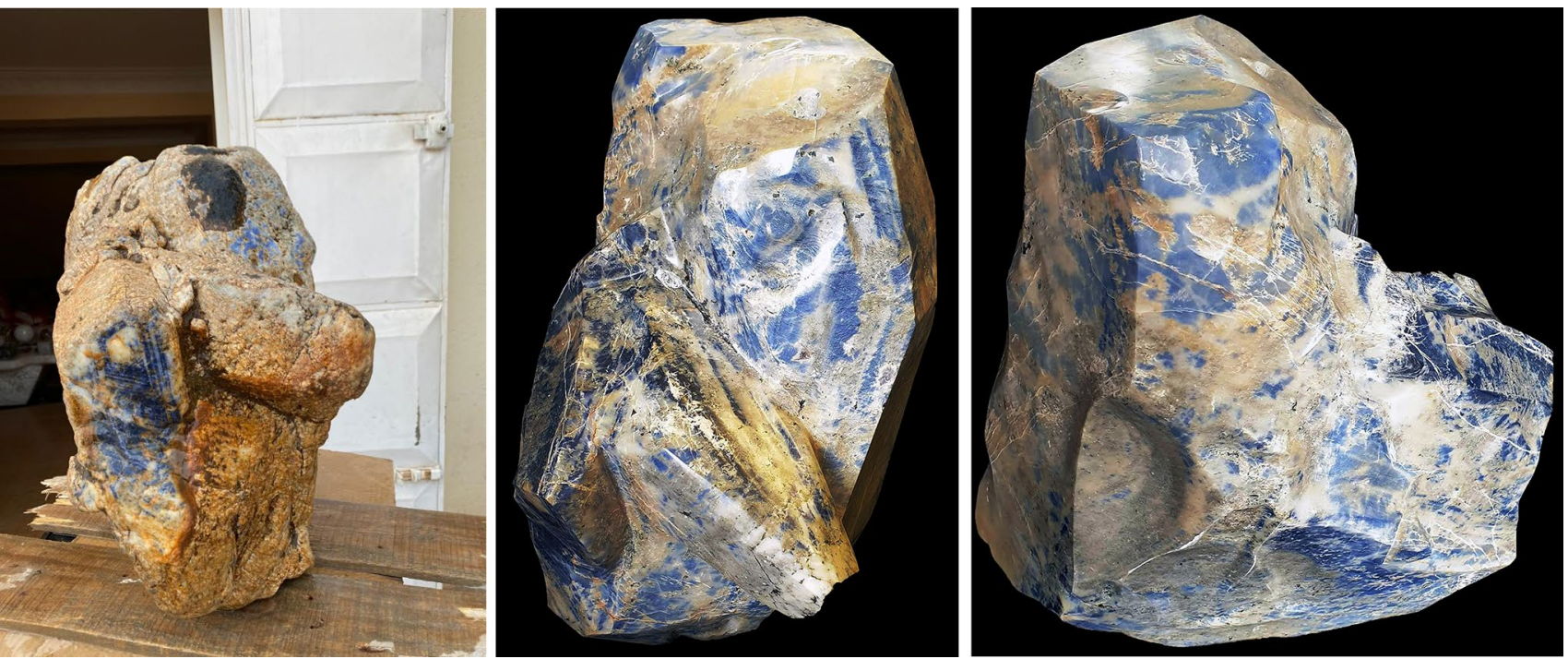

Fig. 17 Cluster of rough sapphire crystals from Madagascar (left), showing partially removed upper layers of iron oxides with clearly visible colour zoning (middle). The roughly shaped and polished specimen (right) named "the priceless sapphire" presently holds the

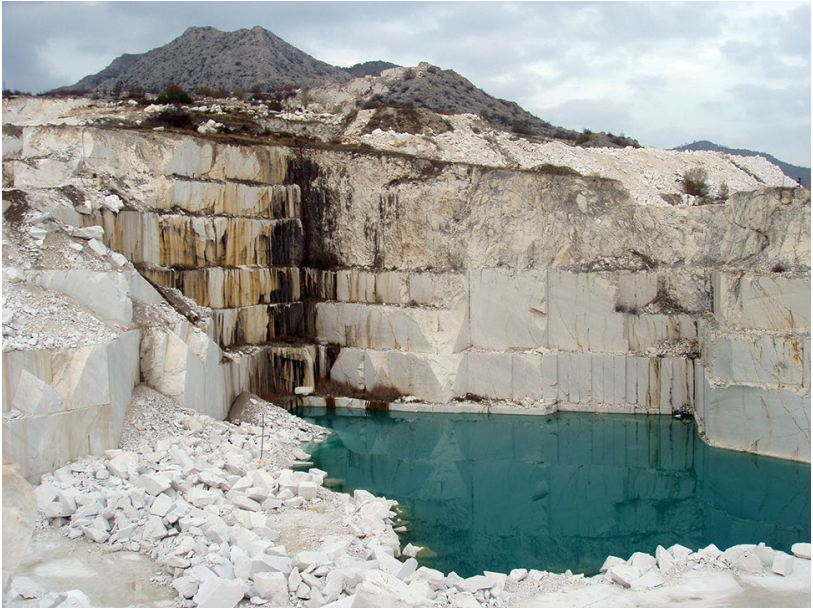

Fig. 18 Quarry of dolomitic marble Sivec near Prilep in North Macedonia. Photo: Zvonko Gruevski

of the largest rubies comes from North Macedonia, where crystals of cabochon quality can grow to reach more than $10 \mathrm{~cm}$ in size. Samples of red corundum originating from Sivec are registered under the name Macedonian Ruby. The mineral's beauty and uniqueness have been acknowledged, and ruby specimens decorate the Order of the Republic of North Macedonia, awarded by the decree of the President of the Republic [95]. The ornamentation contains 320 brilliants and rubies; 133 rubies $(1.25 \mathrm{~mm})$ are embedded in the necklace, whereas 30 cabochon rubies $(2.7 \mathrm{~mm})$ are positioned at each arm of the central star [95]. A beautiful specimen of the
Guinness World Record for the largest carved sapphire $(90.3 \mathrm{~kg}$, $451,500 \mathrm{ct}, 51 \mathrm{~cm} \times 46 \mathrm{~cm} \times 27 \mathrm{~cm}$ ). Photo source: SM Share Management AG, Switzerland

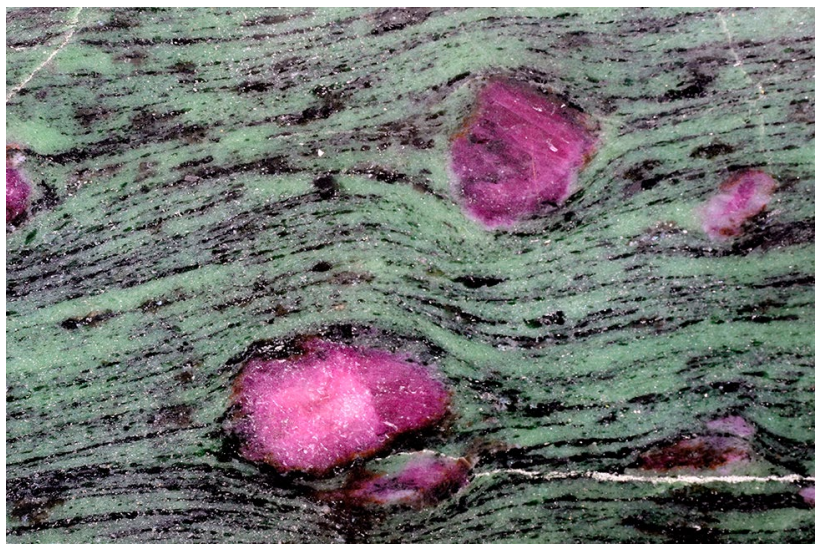

Fig. 19 Porphyroblasts of rubies with zoisite and hornblende from Tanzania, $70 \times 48 \mathrm{~mm}$. Collection: Marjetka Kardelj. Photo: Miha Jeršek

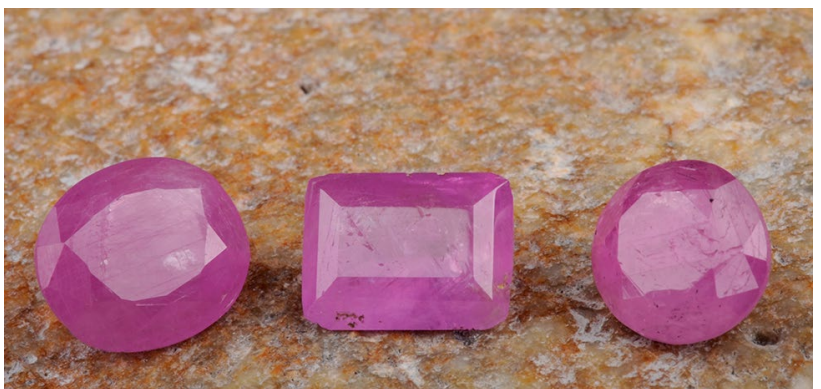

Fig. 20 Faceted rubies from North Macedonia (3.85 ct, 3.40 ct, 3.20 ct). Collection: Marjetka Kardelj. Photo: Miha Jeršek 
unique Macedonian ruby was built into the handle of the first "Macedonian officer sword of honour" of the Macedonian Army Honour Battalion (2018), promoted by the President's Cabinet. The handle was also decorated with several crystals of lorandite as an additional very rare Macedonian mineral.

Sapphires are blue-coloured corundum of gem quality. The colour is due to the presence of $\mathrm{Ti}$ and $\mathrm{Fe}$. Nevertheless, colourless sapphires (leucosapphires) and other coloured (all colours except for red) varieties are also known. The presence of $\mathrm{Fe}$ itself contributes to the appearance of sapphires with a pale green, yellow or brownish colour, but the additional presence of $\mathrm{Ti}$ in the sapphires manifests green, bluegreen or pure blue colours [96]. The blue colour of sapphires in the presence of $\mathrm{Ti}$ and $\mathrm{Fe}$ is caused by a charge transfer mechanism involving both ions [97]. The incorporation of $\mathrm{V}, \mathrm{Ni}$ and Co also influences the colour of sapphires [96]. The yellow colour of sapphires appears as a result of the presence of a colour centre [96]. The finest blue sapphires are found in Kashmir, and exhibit a slightly violet-blue colour, highly saturated in medium to medium-dark tones, known as cornflower blue. Very fine-quality sapphires come from Myanmar. These are also slightly violet-blue, but may appear pinkish under incandescent light. The blue colour of Burmese sapphire is described as royal blue. Sapphires from Sri Lanka are lighter, sometimes greyish and violet blue. Similar to the rubies from Sri Lanka, sapphires are very brilliant. Sapphires from Thailand are even darker, with an intense dark blue colour. Sapphires from Australia are blue, blue-green or yellow, often with a strong dichroism. Montana sapphires from the USA are highly transparent and light in tone. Over the last 20 years, the most important deposits of sapphires lie in Madagascar [11]. Corundum from Sivec dolomitic marble is rarely blue coloured (colour that comes from Ti presence) [51]. Blue-coloured sapphires from North Macedonia are translucent to opaque, suitable for carving and cabochon cutting, and do not show any fluorescence.

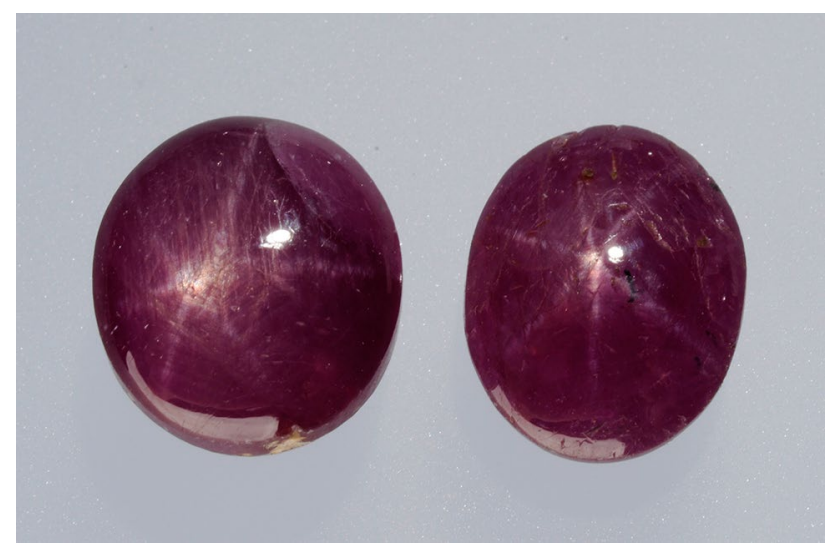

Fig. 21 Star rubies from India $(6.15 \mathrm{ct}, 3.85 \mathrm{ct})$. Collection: Christoph Steidl Porenta, "Zlato runo" jewellery. Photo: Miha Jeršek

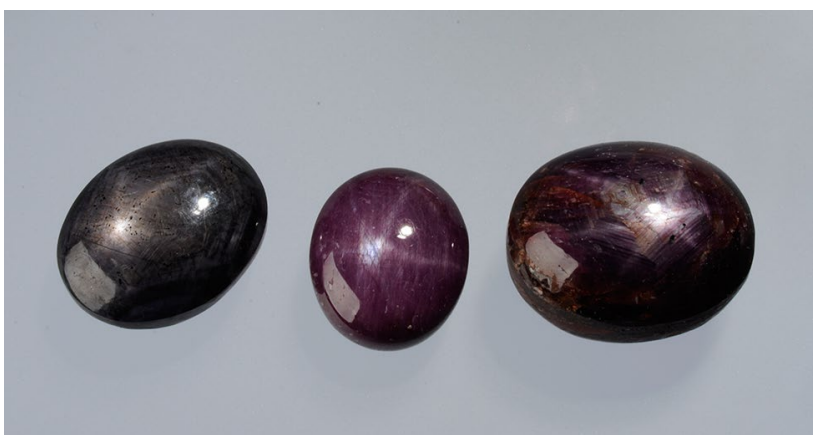

Fig. 22 Star sapphire $(29.30 \mathrm{ct})$ and two star rubies $(18.90 \mathrm{ct}$, $100.95 \mathrm{ct}$ ) from India. Collection: Christoph Steidl Porenta, "Zlato runo" jewellery. Photo: Miha Jeršek

Asterism (exhibiting a luminous star-like shape of gemstones when cut, shaped and polished) is a well-known optical phenomenon in many gem types, including rubies and sapphires, caused by the oriented intergrowth of rutile crystal in the host corundum crystal. When the gem is cut en cabochon, the optical phenomenon exhibits an apparent visible star on the surface of the stone. Corundum has a sixfold symmetry, which explains the six-arm star on rubies and sapphires (Figs. 21 and 22). In the case of complex orientation of rubies (parallel not just to one kind of prism face, but also parallel to first- and second-order prism faces), 12 arms emerge in the star. Star rubies and sapphires are transparent to opaque, and occur mostly in light- to dark-red or purple-red colours; however, all colours are allowed, with the exceptions of orange and yellow. The richest deposits of star rubies are in India, but the finest samples come from Myanmar. The finest star sapphires and star rubies of very good quality are found in Sri Lanka. Rubies from Macedonia do not show asterism.

Trapiche rubies and sapphires are among the rarest gemstones. The trapiche phenomenon was first described in emeralds from Columbia in 1879, and was revisited in detail

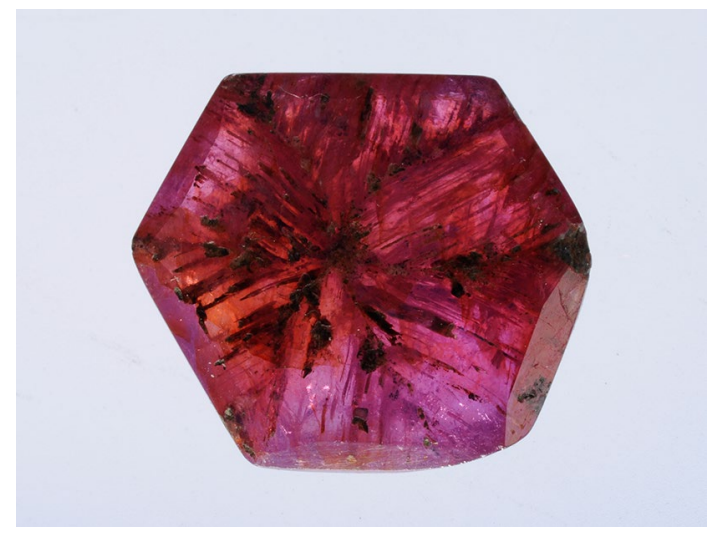

Fig. 23 Trapiche ruby from Vietnam $(18.21 \mathrm{ct})$. Collection: Marjetka Kardelj. Photo: Miha Jeršek 


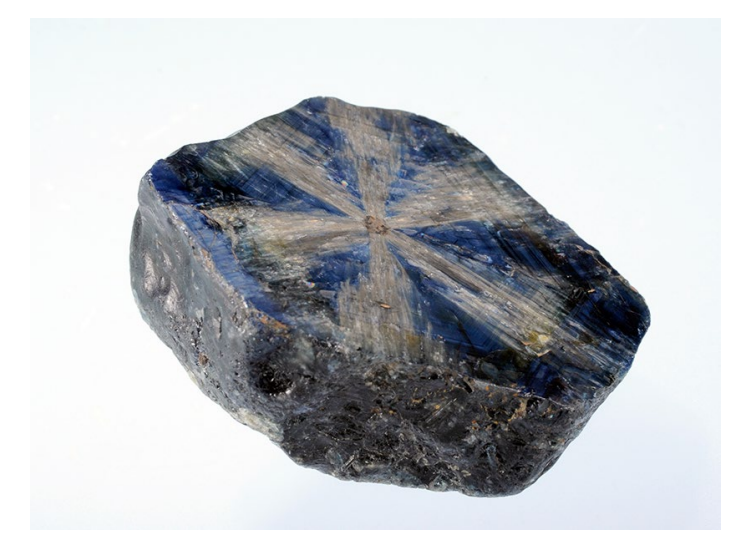

Fig. 24 Ultra-large trapiche-like sapphire from Vietnam $(640.10 \mathrm{ct})$. Collection: Marjetka Kardelj. Photo: Miha Jeršek

only a few years ago [98]. A trapiche emerald is a cluster of oriented crystals around a central crystal. Each crystal grows perpendicular to the prism crystal face. The interior between crystals is filled with albite, quartz and carbon impurities [45]. Trapiche rubies have been known since 1995, and are excavated in Vietnam (Fig. 23), Guinea, Kashmir, Pakistan, Nepal, Sierra Leone and Tajikistan. There are two types of trapiche rubies-those similar to the already described trapiche emerald, and others which are connected to crystal growth of minerals in dendritic forms. These also separate ruby crystals into six sectors. Trapiche-like sapphires were discovered in 1996, and are scarcely discovered in Australia, Cambodia, China, France, Kenya, Madagascar, Nepal, Sri Lanka, Tanzania and Vietnam (Fig. 24). At first, they appear as a crystal of sapphire with the inclusion of rutile in sixfold symmetry. The star rays are not related to any other mineral but corundum. Corundums from Sivec dolomitic marble do not show characteristics of trapiche rubies or sapphires.

The gemmological term diasporescence is the rarest optical phenomenon, resembling a silver glitter, which manifests a white reflection on the surface of cabochon [51]. The feature is registered only in rubies from the Sivec locality in North Macedonia (Fig. 25). Diaspore in Macedonian corundum crystals is oriented in three directions, crossing at $60^{\circ}$, resembling a sagenite-like structure $[99,100]$. The characteristic silver glitter of diaspore in corundum is most intense in the direction of rhombohedron faces, explaining the need to cut the corundum samples parallel to rhombohedron planes, thereby obtaining marked diasporescence on cabochons [20].

\section{Inclusions in rubies and sapphires}

Materials enclosed within gemstones are known as inclusions [101]. Geologists consider the inclusions according to the time of their formation with regard to the host

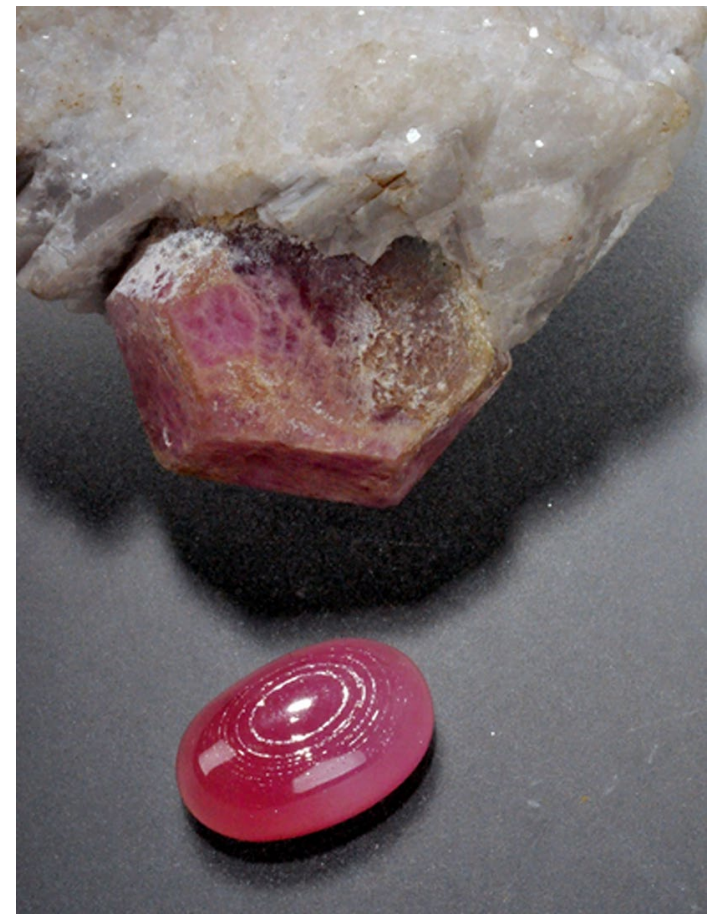

Fig. 25 Diasporescence in ruby from North Macedonia (crystal size $27 \times 27 \mathrm{~mm}$ ). Photo: Miha Jeršek

mineral. In this respect, inclusions may have occurred before the host mineral was formed (protogenetic), were formed at the same time as the host mineral (syngenetic) or formed after formation of the host crystal (epigenetic). "Solid phase" inclusions refer to other crystals trapped in the mineral host; however, inclusions may also appear as either a liquid phase or two gas-liquid phases, but occasionally the mineral hosts all three aggregate forms-solid, liquid and gaseous. Analysis of inclusions helps geologists to understand the conditions under which the host's minerals have crystallised, as well as their evolution through geological history. For gemmologists, however, inclusions are extremely important identification markers in determination of gems' species and origin. In addition to solid and liquid inclusions, gemmologists are also interested in determining cleavage cracks, fractures, growth lines and colour zoning [101]. Inclusions are always present in gems. Rubies and sapphires have very recognisable inclusions, some of which are typical only for particular deposits.

Inclusions in rubies and sapphires are extremely important, and typically described separately for each location, as presented for the Bo Welu gem deposit in Chanthaburi, Thailand [26]. In general, the most significant inclusions in rubies and sapphires are silk (Fig. 26), rutile (Fig. 27), zircon crystals, healing feather, growth lines, colour zoning and fingerprint inclusions. 


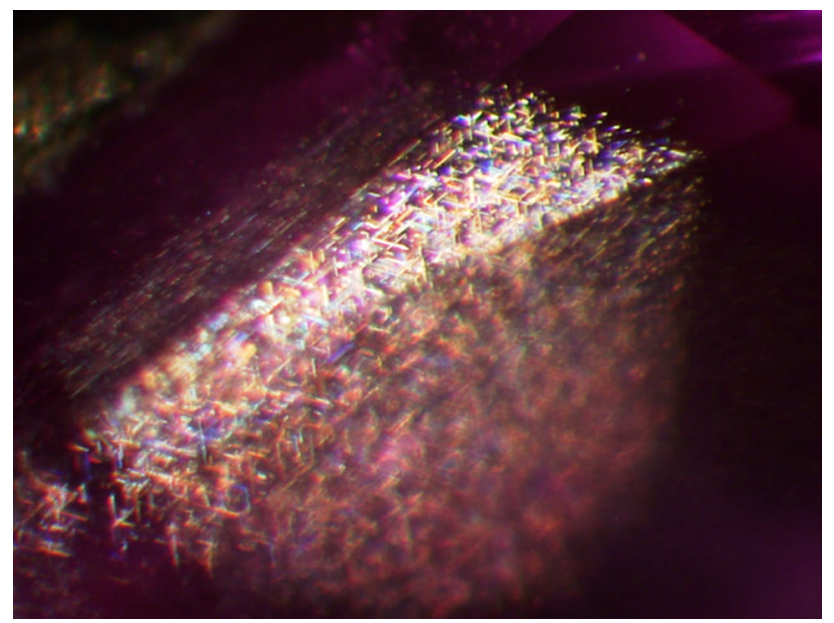

Fig. 26 Intersecting of rutile crystals (silk) in ruby from Myanmar, $3 \times 2 \mathrm{~mm}$. Photo: Miha Jeršek

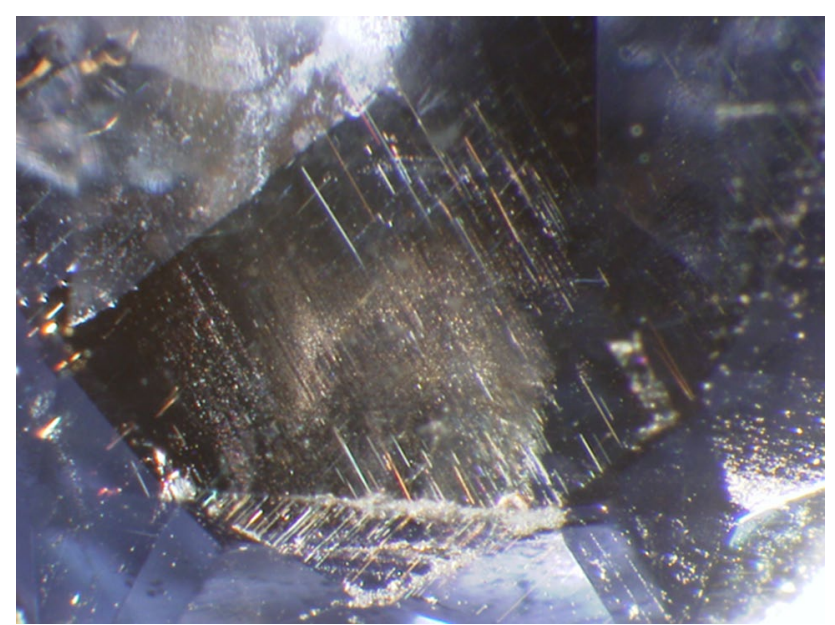

Fig. 27 Rutile needles in sapphire from Sri Lanka, $3 \times 2 \mathrm{~mm}$. Photo: Miha Jeršek

Silks are intersecting needle-like crystals, which exhibit a sheen similar to that of silk fabric when examined under reflected light [101]. Silk in rubies and sapphires comes from fine needle-like crystals of rutile and, rarely, boehmite. Needle-like rutile crystals are often arranged in three sets and intersect each other at $60^{\circ}$ and $120^{\circ}$ angles. The presence of silk in rubies and sapphires proves their genuineness, and is often observed in rubies from Myanmar (Burma) and Kenya, but never in rubies from Thailand [101]. Rubies from Myanmar (Fig. 28) and rubies and sapphires from Thailand have typical inclusions of pyrrhotite, with a cloud-like yellowish-brown veil. Such inclusions are, thus, named ball-like inclusions [101]. Rubies and sapphires from Thailand and, rarely, rubies from Myanmar exhibit various twinning planes. Halo or

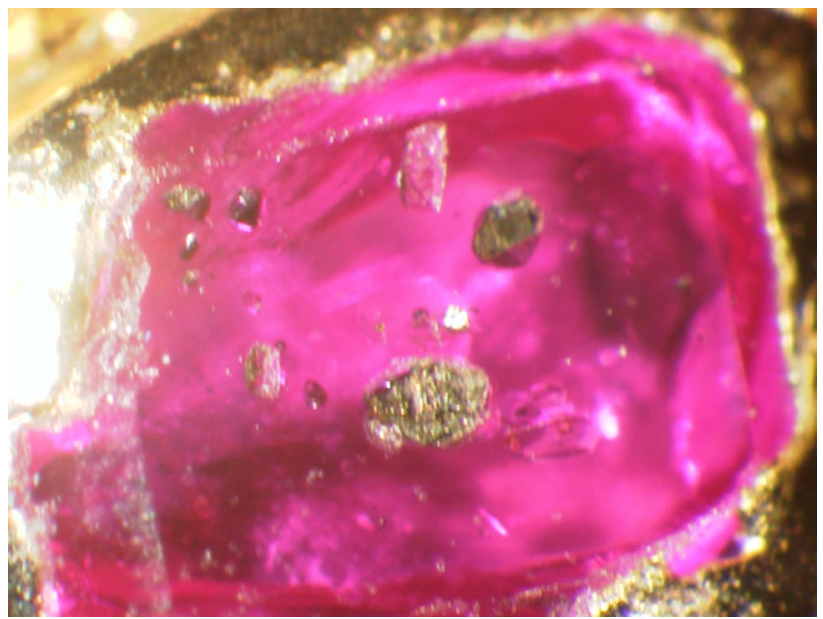

Fig. 28 Pyrrhotite crystal and holes in ruby from Myanmar, $4 \times 2.5$ mm. Photo: Miha Jeršek

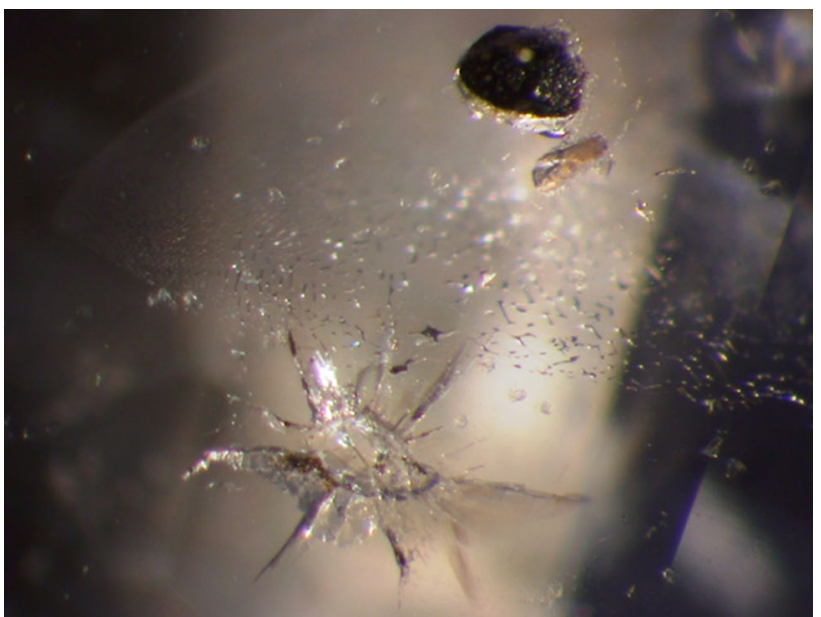

Fig. 29 Halo inclusion in sapphire from Sri Lanka, $2 \times 1.3 \mathrm{~mm}$. Photo: Miha Jeršek

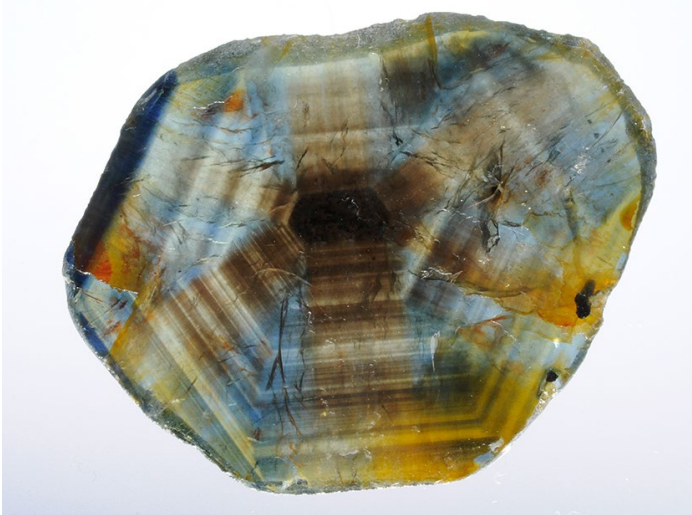

Fig. 30 Colour zoning in trapiche-like sapphire from Vietnam (38.75 ct). Collection: Marjetka Kardelj. Photo: Miha Jeršek 
disc-like inclusions are typical inclusions where small zircon crystals, usually dark coloured, are surrounded by flat disc-like wings (Fig. 29).

Healing feather is a liquid-filled inclusion consisting of a maze-like arrangement of tubes. These inclusions are characteristic of rubies and sapphires from Cambodia and Sri Lanka [101]. Fingerprints are inclusions of small crystals arranged in curved rows. Growth lines in rubies and sapphires show sixfold symmetry of corundum crystals. The same distribution could affect colour in rubies and sapphires, and such inclusions are described as colour zoning (Fig. 30).

Diaspore, calcite, dolomite, muscovite, margarite, rutile and chlorite are the most common solid inclusions in rubies from North Macedonia [51]. Rubies from North Macedonia are opaque to translucent, and rarely transparent. For the determination of inclusions in Macedonian rubies, a thin preparation of samples is needed. Only the presence of diaspore is easily recognisable, even to the naked eye. Diaspore is rarely seen in rubies from around the world, but is a normal phenomenon in Macedonian rubies. Diaspore intergrows in two ways: (1) by oriented interposition of corundum and diaspore-this can be observed on pinacoids, hexagonal prisms and hexagonal bipyramids; and (2) by lamellar intergrowth of diaspores - this can be observed on rhombohedral forms of corundum [51]. Each ruby from North Macedonia has inclusions of diaspore, resembling the silver glitter of gems. Diaspore inclusions are the element of recognisability of rubies, after which their origin can also be determined [51].

\section{Synthetic rubies and synthetic sapphires}

Macedonian rubies are distinct and unique, and no confusion with any synthetic gemstones is expected. Nevertheless, the production of synthetic rubies and synthetic sapphires should be mentioned because of the enormous increase in the scale of their trade. Commercial production of synthetic rubies began in 1905 and accelerated in 1911 with the blue synthetic sapphires fabricated in a Verneuil flame-fusion process [102, 103]. In this process, the source for synthetic corundum is highly purified alumina. Alumina sits on the bottom of an enclosed chamber, on the other side of which oxygen (under high pressure) is introduced into and carries the fine alumina particles into the intense heat of the central part of an oxyhydrogen flame. The particles fuse and fall as droplets to the molten upper surface of the boule. The temperature of the upper surface of the boule is held just above the melting point $\left(2030{ }^{\circ} \mathrm{C}\right.$ for colourless corundum). This results in the formation of up to a 200-ct boule of synthetic ruby or synthetic sapphire, depending of the type of oxides added into the process. Such synthetic rubies have very characteristic curved growth striations and extremely strong red fluorescence under UV-LW radiation.

After 1920, Czochralski [2, 14, 103] invented the pulling method for preparing synthetic rubies, producing large and very clean synthetic rubies. This crystal-growth technique is based on melting, comprising corundum as starting material which is slowly pulled away. As a result, a single crystal of high gem quality is fabricated.

In a flux growth method, the composition of the desired synthetic crystal (i.e. aluminium oxides) is mixed with a flux material that reduces the melting point to the degree where it becomes supersaturated. At this temperature, rubies or sapphires precipitate out and grow on the seed crystals. These crystals have parallel colour zoning and show strong red fluorescence in UV-LW. Rubies crystallised using flux growth methods came to market during the mid-1960s. Small, irregularly shaped and elongated bubbles are the most significant inclusions [101]. Chatham, Kashan and Ramaura rubies are synthetic analogues produced using the flux growth method. Star rubies and star sapphires were manufactured using the Verneuil flame-fusion method in 1947.

The ongoing mass production of lab-grown synthetic rubies and sapphires has led to a decrease in their price. The value of these lab specimens depends on the growth method and costs of cutting, and range in trade from just a few USD/carat up to $10 \mathrm{USD} /$ carat, and rarely more. On the other hand, natural sapphires and rubies are categorised among the most highly praised and priced gemstones. The intensely red-coloured specimens of rubies with vivid levels of saturation can reach prices of more than 1 million USD/ carat.

\section{Other uses of corundum}

Corundum is used as an abrasive, grinding and polishing material owing to its high hardness [78]. Corundum for abrasives consists of its mixture with hematite, spinel and magnetite, and exists as a dark-coloured rock named emery. The relative hardness of emery is 8 on the Mohs scale. Turkey and Greece are the main suppliers of the world's emery.

In the mid-nineteenth century, watchmakers in Switzerland needed as thin a bearing as possible that would be resistant to wear, and realized they could drill the corundum crystal and use it for this purpose. Corundum was found to be much more resilient and had a longer lifespan than metal bearings. At the beginning of the twentieth century, watchmakers started using synthetic corundum for this purpose. Synthetic corundum (especially ruby) bearings are still present in mechanical watches. Synthetic colourless sapphire, however, is used by watchmakers in both mechanical and 
digital watches as a glass overlay owing to its durability, hardness, lack of colour and vitreous lustre [3].

Theodore Harold Maiman (1927-2007) from Hughes Research Laboratories constructed the first "ruby" laser in 1960 [104]. The intense light of the laser beam resulted from a short chain reaction of the original light, which is amplified in the gain medium (the ruby crystal), in such a way that the electrons move to a higher energy level. In addition to synthetic ruby, synthetic sapphires with Ti grip were also used for lasers. Lasers became very popular in applications such as in CD and DVD players, for cutting metal and stone, for removing tattoos, as well as in various branches of medicine and surgery.

Synthetic corundum is extremely hard, colourless, transparent, scratch-resistant, chemically inert and resistant to heat, having versatile applications in optics, space equipment, aircraft windows and protective covers for electronic devices, among others [103].

\section{Conclusions}

Corundum remains a highly important industrial mineral, particularly as an abrasive and, owing to its optical properties, in optics, corundum-based ceramics and in space equipment. As a gemstone, ruby and sapphire remain among the most desirable stones in jewellery.

Many new deposits of these two corundum varieties were discovered over the last several decades. Vietnam and Madagascar became the leading worldwide exporters of natural gemstones for rubies and sapphires, respectively, in parallel to the constant rise of the world's demand for synthetic rubies and sapphires.

Trapiche rubies and trapiche-like sapphires are relatively new, rare and unique gemstones.

Beside star rubies and star sapphires, rubies with the optical phenomenon diasporescence also have a new role in trade. Diasporescence is characteristic only for rubies hidden in the dolomitic marble in North Macedonia. The oriented intergrowth of diaspore in corundum parallel to rhombohedra leads to a silver glitter of rubies, and applies to other physical characteristics of rubies from North Macedonia.

Corundums from North Macedonia appear in a wide range of morphological forms. Characteristic corundums are tabular and have prismatic habits, while bipyramidal and rhombohedral habits are rarer. The crystals are partially corroded and rarely preserved in calcite nests in marbles, showing forms with a high lustre. Oriented intergrowth with diaspores parallel to rhombohedral crystal faces is responsible for the parting of corundum crystals. Inclusions of diaspore have a large influence on the overall appearance of corundum crystals. They are opaque to translucent, and very rarely transparent. Chromium impurities make them red coloured, while the presence of $\mathrm{V}$ and $\mathrm{Fe}$ contributes more rose to violet and violet to red colours. Rarely, these may also be blue coloured as a result of $\mathrm{Ti}$ impurities. For gem-quality specimens, this implies that corundums from North Macedonia are rubies and sapphires, too. The presence of diaspore in gem-quality corundum is responsible for the lower density $\left(3.55-3.93 \mathrm{~g} \mathrm{~cm}^{-3}\right)$ and for the approximately $10 \%$ lower hardness of rubies and sapphires from Prilep dolomitic marble. The samples exhibit distinct red, orange and even yellow fluorescence. Many crystal specimens show twocoloured fluorescence, red and orange, which exemplify the sixfold symmetry of the differently coloured zones.

Classical testing methods, as presented in this article, are welcome in the gemmology trade. For the scientific point of interest, more complex studies must be undertaken. Classic crystallographic studies revealing crystallogenetic trends and aspects are rare among current publications.

Nowadays, scientists study geochemistry and isotopic compositions of corundum (regardless of whether the sample is gem-quality or not), and scan the geological features of the deposits and the mineral quantity and quality.

Rubies from North Macedonia are rarely described and scarcely discussed in the scientific literature and corundum textbooks. Nevertheless, they remain of great interest for further investigation to propel new domains into understanding the fascinating world of rubies and sapphires.

\section{References}

1. International Mineralogical Association. http://cnmnc.main. jp. Accessed 27 March 2021

2. Tomaszewski PE (2002) Jan Czochralski-father of the Czochralski method. J Cryst Growth 236:1-4

3. Isler P (2003) Watches: mechanical materials. In: Buschow KHJ (ed) Encyclopedia of materials: science and technology, 2nd edn. Elsevier, Oxford, pp 1-17

4. García-Lastra JM, Barriuso MT, Aramburu JA, Moreno M (2005) Origin of the different color of ruby and emerald. Phys Rev B 72:113104

5. Boev B, Jovanovski G, Makreski P, Bermanec V (2005) Minerals from Macedonia. XV. Sivec mineral assemblage. Geologica Macedonica 19:39-56

6. Chandler DE, Majumdar ZK, Heiss GJ, Clegg RM (2006) Ruby crystal for demonstrating time- and frequency-domain methods of fluorescence lifetime measurements. J Fluoresc 16:793-807

7. Gaudry É, Sainctavit P, Juillot F, Bondioli F, Ohresser P, Letard I (2006) From the green color of eskolaite to the red color of ruby: an X-ray absorption spectroscopy study. Phys Chem Minerals 32:710-720

8. Garnier V, Maluski H, Giuliani G, Ohnenstetter D, Schwarz D (2006) $\mathrm{Ar}-\mathrm{Ar}$ and U-Pb ages of marble-hosted ruby deposits from central and southeast Asia. Can J Earth Sci 43:509-532

9. Garnier V, Giuliani G, Ohnenstetter D, Fallick AE, Dubessy J, Banks D, Vinh HQ, Lhomme T, Maluski H, Pêcher A, Bakhsh KA, Long PV, Trinh PT, Schwarz D (2008) Marble-hosted 
ruby deposits from Central and Southeast Asia: towards a new genetic model. Ore Geol Rev 34:169-191

10. Simonet C, Fritsch E, Lasnier B (2008) A classification of gem corundum deposits aimed towards gem exploration. Ore Geol Rev 34:127-133

11. Shor R, Weldon R (2009) Ruby and sapphire production and distribution: a quarter century of change. Gems Gemol 45:236-259

12. Jovanovski G, Boev B, Makreski P (2012) Minerals from the Republic of Macedonia with an introduction to mineralogy. Macedonian Academy of Sciences and Arts, Skopje

13. Bristow JK, Parker SC, Catlow CRA, Woodley SM, Walsh A (2013) Microscopic origin of the optical processes in blue sapphire. Chem Commun 49:5259-5261

14. Sangwal K (2013) Czochralski method of crystal growth in the scientific literature: an informetric study. Acta Phys Pol 124:173-180

15. Reddy SL, Endo T, Reddy GS (2012) Electronic (absorption) spectra of 3d transition metal complexes. In: Farrukh MA (ed) Advanced aspects of spectroscopy. InTech, Rijeka, pp 1-48

16. Rakotosamizanany S, Giuliani G, Ohnenstetter D, Rakotondrazafy AFM, Fallick AE, Paquette J-L, Tiepolo M (2014) Chemical and oxygen isotopic compositions, age and origin of gem corundums in Madagascar alkali basalts. J Afr Earth Sci 94:156-170

17. Bristow JK, Tiana D, Parker SC, Walsh A (2014) Defect chemistry of $\mathrm{Ti}$ and $\mathrm{Fe}$ impurities and aggregates in $\mathrm{Al}_{2} \mathrm{O}_{3}$. J Mater Chem A 2:6198-6208

18. Doménech-Carbó A (2015) Dating: an analytical task. ChemTexts 1:5

19. Vysotskiy SV, Nechaev VP, Kissin AYu, Yakovenko VV, Ignat'ev AV, Velivetskaya TA, Sutherland FL, Agoshkov AI (2015) Oxygen isotopic composition as an indicator of ruby and sapphire origin: a review of Russian occurrences. Ore Geol Rev 68:164-170

20. Jeršek M (2015) Diasporescence in rubies from Prilep dolomitic marble. Maced J Chem Chem Eng 34:139-143

21. Wongrawang P, Monarumit N, Thammajak N, Wathanakul P, Wongkokua W (2016) Oxidation states of Fe and Ti in blue sapphire. Mater Res Express 3:026201-1-026201-7

22. Balmer WA, Hauzenberger CA, Fritz H (2017) Marble-hosted ruby deposits of the Morogoro Region, Tanzania. J Afr Earth Sci 134:626-643

23. Huges R, Manorotkul W, Huges EB (2017) Ruby \& sapphire: a gemologist's guide. RWH/Lotus, Bangkok

24. Hunault MOJY, Harada Y, Miyawaki J, Wang J, Meijerink A, de Groot FMF, van Schooneveld MM (2018) Direct observation of $\mathrm{Cr}^{3+} 3 \mathrm{~d}$ states in ruby: toward experimental mechanistic evidence of metal chemistry. J Phys Chem A 122:4399-4413

25. Yu J, He X, Lu Z (2019) Cause analysis of chatoyancy of sapphires from Shandong, China. RSC Adv 9:24420-24427

26. Promwongnan S, Sutthirat C (2019) Mineral inclusions in ruby and sapphire from the Bo Welu Gem Deposit in Chanthaburi, Thailand. Gems Gemol 55:354-369

27. Palke AC (2020) Coexisting rubies and blue sapphires from major world deposits: a brief review of their mineralogical properties. Minerals 10(472):1-20

28. Dubinski EV, Stone-Sundberg J, Emmett JL (2020) A quantitative description of the causes of color in corundum. Gems Gemol $56: 2-28$

29. Giuliani G, Ohnenstetter D, Garnier V, Fallick AE, Rakotondrazafy AFM, Schwarz D (2007) The geology and genesis of gem corundum deposits. In: Groat LA (ed) Geology of gem deposits, 1st ed. Mineralogical Association of Canada, Short Course Series 37, Yellowknife, Canada, pp 23-78

30. Giuliani G, Fallick A, Rakatondrazafy M, Ohnenstetter D, Andriamamonjy A, Ralantarison TH, Offant Y, Garnier V, Dunbigre $\mathrm{CH}$, Schwarz D (2007) Oxygen isotope systematics of gem corundum deposits in Madagascar. Miner Depos 42:251-270
31. Giuliani G. Ohnenstetter D, Fallick AE, Groat L, Fagan AJ (2014) The geology and genesis of gem corundum deposits. In: Groat LA (ed) Geology of gem deposits, 2nd ed. Mineralogical Association of Canada Short Course, Quebec, vol 44, pp 29-112

32. Giuliani G, Groat A (2019) Geology of corundum and emerald gem deposits: a review. Gems Gemol 55:464-489

33. Giuliani G, Groat LA, Fallick AE, Pignatelli I, Pardieu V (2020) Ruby deposits: a review and geological classification. Minerals 10(597): 1-83

34. Wagner G (1995) Altersbestimmung von jungen Gesteinen und Artefakten. Enke Verlag, Stuttgart

35. Aitken MJ (1990) Science-based dating in archaeology, chapter 1. Longman, New York

36. Graham I, Sutherland L, Zaw K, Nechaev V, Khanchuk A (2008) Advances in our understanding of the gem corundum deposits of the West Pacific continental margins intraplate basaltic fields. Ore Geol Rev 34:200-215

37. Kröner A (1984) Late Precambrian plate tectonics and orogeny: a need to redefine the term Pan-African. In: Klerkx J, Michot J (eds) African geology. Musée Royal de l'Afrique Centrale, Tervuren, pp 23-28

38. Hughes RW (1997) Ruby and sapphire. RWH, Boulder, p 512

39. Vertriest W, Girma D, Wongrawang P, Atikarnsakul U, Schumacher K (2019) Land of origins: a gemological expedition to Ethiopia. Gems Gemol 55:72-88

40. Kissin AJ (1994) Ruby and sapphire from the Southern Ural Mountains, Russia. Gems Gemol 30:243-252

41. Spiridonov EM (1998) Gemstone deposits of the former Soviet Union. J Gemmol 26:111-124

42. Kolstov AB (2002) Ruby-bearing metasomatites in marbles: conditions and numerical mode of formation. Exp Geosci 10:94-96

43. Garnier V (2003) Les gisements de rubis associés aux marbres de l'Asie Centrale et du Sud-est: genèse et caractérisation isotopique. Thèse de Doctorat INPL, Nancy

44. Mercier A, Debat P, Saul JM (1999) Exotic origin of the ruby deposits of the Mangari area in SE Kenya. Ore Geol Rev 14:83-104

45. Eppler WF (1989) Praktische Gemmologie. Rühle-DiebnerVerlag, Stuttgart

46. Klein C (2002) Mineral science. Wiley, New York

47. Kirfel A, Eichhorn K (1990) Accurate structure analysis with synchrotron radiation. The electron density in $\mathrm{Al}_{2} \mathrm{O}_{3}$ and $\mathrm{Cu}_{2} \mathrm{O}$. Acta Crystallogr Part A 46:271-284

48. Finger LW, Hazen RM (1978) Crystal structure and compression of ruby to 46 kbar. J Appl Phys 49:5823-5826

49. Kostov I, Kostov IR (1999) Crystal habits of minerals. Prof. Marin Drinov Academic Publishing House \& Pensoft Publishers, Sofia

50. Schmetzer K (1986) Natürliche und sythetische Rubine. E. Schweizerbart'sche Verlagsbuchhandlung, Stuttgart

51. Jeršek M, Mirtič B (1999) Corundum from Prilep dolomitic marble (Macedonia). Scopolia 41:1-22

52. Žorž M, Jeršek M, Mladenovski G (1999) Nekatera nahajališča mineralov v Makedoniji in njihova parageneza (Some mineral locations in Macedonia and their paragenesis). In: Gogala M (ed) Skrita bogastva Makedonije (Hidden treasures of Macedonia). Scopolia, Suppl. 2, pp 9-63 (in Slovenian and English)

53. Crichton RR (2012) Basic coordination chemistry for biologists. Biological inorganic chemistry: a new introduction to molecular structure and function, 2nd edn. Elsevier, Amsterdam, pp 21-34

54. Burns RG (1993) Outline of crystal field theory. Mineralogical applications of crystal field theory. Cambridge University Press, Cambridge, pp 7-43

55. Moss SC, Newnham RE (1964) The chromium position in ruby. Z Kristallogr 120:359-363 
56. Fritsch E, Rossman GR (1987) An update on color in gems. Part 1: introduction and colors caused by dispersed metal ions. Gems Gemol 23:126-139

57. Fritsch E, Rossman GR (1988) An update on color in gems. Part 2: colors involving multiple atoms and color centers. Gems Gemol 24:3-15

58. Emmett JL, Dubinsky EV, Hughes RW, Scarratt K (2017) Color, spectra \& luminescence. In: Hughes RW (ed) Ruby \& sapphire: a gemologist's guide. RWH/Lotus, Bangkok, pp 107-163

59. Emmett JL, Stone-Sundberg J, Guan Y, Sun Z (2017) The role of silicon in the color of gem corundum. Gems Gemol 53:42-47

60. Stone-Sundberg J, Thomas T, Sun Z, Guan Y, Cole Z, Equall R, Emmett JL (2017) Accurate reporting of key trace elements in ruby and sapphire using matrix-matched standards. Gems Gemol 53:438-451

61. Burns RG (1981) Intervalence transitions in mixed-valence minerals of iron and titanium. Ann Rev Earth Planet Sci 9:345-383

62. Moon AR, Phillips MR (1994) Defect clustering and color in Fe,Ti: $\alpha-\mathrm{Al}_{2} \mathrm{O}_{3}$. J Am Ceram Soc 77:356-367

63. Harlow GE, Bender W (2013) A study of ruby (corundum) compositions from the Mogok Belt, Myanmar: searching for chemical fingerprints. Am Mineral 98:1120-1132

64. Zaw K, Sutherland L, Yui T-F, Meffre S, Thu K (2015) Vanadium-rich ruby and sapphire within Mogok Gemfield, Myanmar: implications for gem color and genesis. Miner Deposita 50:25-39

65. Nassau K (2001) The physics and chemistry of colour, 2nd edn. Wiley, New York

66. Kvapil J, Perner B, Sulovsky J, Kvapil J (1973) Colour centre formation in corundum doped with divalent ions. Krist Tech 8:247-251

67. Emmett JL, Scarratt K, McClure SF, Moses T, Douthit TR, Hughes R, Novak S, Shigley JE, Wang W, Bordelon O, Kane R (2003) Beryllium diffusion of ruby and sapphire. Gems Gemol 39:84-135

68. Kröger FA (1984) Defect related properties of doped alumina. Solid State Ionics 12:189-199

69. Schmetzer K (1981) The colour of natural corundum. Neues Jahrb Mineral Monatsh 2:59-68

70. Schmetzer K, Bosshart G, Hänni HA (1983) Naturally-coloured and treated yellow and orange-brown sapphires. J Gemmol 18:607-622

71. Boiko BB, Shkadarevich AP, Zhdanov ÉA, Kalosha I, Koptev VG, Demidovich AA (1987) Lasing due to color centers in an $\mathrm{Al}_{2} \mathrm{O}_{3}: \mathrm{Mg}$ crystal. Sov J Quantum Electron 17:581-582

72. Emmett JL, Douthit TR (1993) Heat treating the sapphires of Rock Creek Montana. Gems Gemol 29:250-272

73. Häger T (2001) High temperature treatment of natural corundum. In: Hofmeister E, Dao NQ, Quang VX (eds) Proceedings of the international workshop on material characterization by solid state spectroscopy: the minerals of Vietnam, Hanoi, pp 24-37

74. Long PV, Vinh HQ, Gamier V, Giuliani G, Ohnenstetter D, Lhomme T, Schwarz D, Fallick A, Dubessy J, Trinh PT (2004) Gem corundum deposits in Vietnam. J Petrol 29:129-148

75. Pala International. Questions about treated sapphires from Thailand. http://www.palagems.com/bulk-diffusion-sapphire. Accessed 27 Mar 2021

76. Shtukenberg A, Punin YO (2007) Crystal optics. In: Kahr B (ed) Optically anomalous crystals. Springer, Dordrecht, pp 1-34

77. Mineralogical Society of America. Mohs' scale of hardness. http://www.minsocam.org/msa/collectors_corner/article/mohs. htm. Accessed 27 Mar 2021

78. Bauer M (1968) Precious stones, vol II. Dover, New York

79. Gem reference guide (1995) Gemological Institute of America, Santa Monica

80. Edinburgh Instruments. What is a Jablonski diagram (PerrinJablonski diagram)?https://www.edinst.com/us/blog/jablonskidiagram/. Accessed 27 Mar 2021

81. Henn U (1990) Gemmologisches Praktikum, eine Sonderveröffentlichung von Gold + Silber + Uhren + Schmuck. Robert Kohlhammer GmbH, Leinfelden-Echterdingen
82. Robertson ADC, Sutherland FJ (1992) Possible origins and ages for sapphire and diamond from the central Queensland gemfields. Rec Austral Museum Suppl 15:45-54

83. Upton B, Hinton RW, Aspen P, Finch A, Valley JW (1999) Megacrysts and associated xenoliths, evidence for migration of geochemically enriched melts in the upper mantle beneath Scotland. J Petrol 40:935-956

84. Mondadory A (1991) Rocks and minerals. Macdonald, London

85. Mindat.org. http://www.mindat.org. Accessed 27 Mar 2021

86. Barić Lj (1977) Im Weisen Marmor. Lapis 2:10-12

87. Stojanov R (1960) Prethodni rezultati od geološkite i petrografskite istražuvanja na visokometamornite steni vo centralniot del na Pelagonski masiv (Previous results of geological and petrographic investigations of high metamorphic rocks in the central part of Pelagonian massif). Geološki Zavod NRM 7:147-177 (in Macedonian)

88. Barić Lj (1969) Dolomitmarmor in der Umgebung der Stadt Prilep und die in ihm vorkommenden Minerale. Tscher Miner Petrog Mitt 13:233-249

89. Žorž M, Vidrih R, Kobler G (1991) Minerali Prilepskega marmorja (Minerals in Prilep's marbles). Proteus 53:243-251 (in Slovenian)

90. Barić Lj (1979) Diaspor, ein ungewöhnlich grosser kristall aus dem dolomit-steinbruch Sivec unweit von Prilep in Mazedonien. Jugoslawien Lapis 4:25

91. Henn U (1995) Edelsteinkundliches Praktikum. Deutsche Gemmologische Gesellschaft, Idar-Oberstein

92. Gübelin EJ (1982) Gemstones of Pakistan: emerald, ruby, and spinel. Gems Gemol 18:123-139

93. Chualaowanich T, Sutthirat C, Pisuttha-Arnond V, Hauzenberger C, Chinghua L, Tongyi L, Charusiri P (2014) Geochemical characteristic and new eruption ages of ruby-related basalts from Southeast Kenya. J Earth Sci 25:799-821

94. Henn U, Bank H, Bank-Scherner M (1990) Rubine aus der PamirGebirge, UdSSSR. Z Dt Gemmolog Ges 4:201-205

95. Official Gazette of the Republic of North Macedonia, no. 23, 3rd February 2020. https://www.slvesnik.com.mk/Issues/be3a2aba25 4a4ed5a365076af3e596d0.pdf

96. Nassau K (1994) Gemstone enhancement. Butterworth-Heineman, Oxford

97. Townsend MG (1968) Visible charge transfer band in blue sapphire. Solid State Commun 6:81-83

98. Pignatelli I, Giuliani G, Ohnenstetter D, Agrosi G, Mathieu S, Moriot C, Brancquet Y (2015) Colombian trapiche emeralds: recent advances in understanding their formation. Gems Gemol $51: 222-259$

99. Barić Lj (1960) Optische eingeschaften des diaspors von Sivec unweit von Prilep in Mazedonien (Optical properties of the diaspore from Sivec not far from Prilep in Macedonia). Bull Sci Conseil Acad RPF Yougoslavie 5:71

100. Barić $\mathrm{Lj}$ (1963) Über die orientirte verwachsung des diaspors und des korunds von Sivec in Mazedonien. Beitr zur Min u Petr 9:133-138

101. Matlins AL, Bonanio AC (1989) Gem identification made easy. Gemstone, South Woodstock

102. Tomaszewski PE (1998) Professor Jan Czochralski (1885-1953) and his contribution to the art and science of crystal growth. AACG Newslett 27:12-18

103. Nassau K (1972) Dr. A.V. L. Verneuil: the man and the method. J Cryst Growth 13/14:12-18

104. King HM. Corundum. https://geology.com/minerals/corundum. shtml. Accessed 27 Mar 2021

Publisher's Note Springer Nature remains neutral with regard to jurisdictional claims in published maps and institutional affiliations. 